$10-1-1980$

\title{
The Governmental-Proprietary Distinction in Constitutional Law
}

Michael L. Wells

University of Georgia School of Law, mwells@uga.edu

Walter Hellerstein

University of Georgia School of Law, wallyh@uga.edu

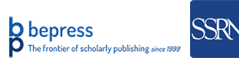

\section{Repository Citation}

Michael L. Wells and Walter Hellerstein, The Governmental-Proprietary Distinction in Constitutional Law (1980),

Available at: https://digitalcommons.law.uga.edu/fac_artchop/379

This Article is brought to you for free and open access by the Faculty Scholarship at Digital Commons @ University of Georgia School of Law. It has been accepted for inclusion in Scholarly Works by an authorized administrator of Digital Commons @ University of Georgia School of Law. Please share how you have benefited from this access For more information, please contact tstriepe@uga.edu. 


\section{THE GOVERNMENTAL-PROPRIETARY DISTINCTION IN CONSTITUTIONAL LAW}

\section{Michael Wells* and Walter Hellerstein**}

THE governmental-proprietary distinction has led a stormy 1 life. Courts have characterized it as "illusory," a "quagmire," a "rule of law that is inherently unsound,"s and as a "talismanic formula" that results in "unenhightening characterizations of States' activities." Commentators have branded the distinction as "probably one of the most unsatisfactory known to the law," have questioned its internal coherence, ${ }^{7}$ and have dismissed it as irrelevant in constitutional decisions. ${ }^{8}$ The distinction, however, clings stubbornly to life, appearing in a remarkably wide range of cases. ${ }^{9}$

* Assistant Professor of Law, University of Georgia.

**Associate Professor of Law, University of Georgia.

The authors wish to thank Gregory S. Alexander, Richard A. Posner, Paul H. Rubin, Geoffrey R. Stone, and participants in the Law and Economics Workshop at the University of Chicago Law School for their helpful comments on an earlier draft of this article.

1 Township of Washington v. Village of Ridgewood, 26 N.J. 578, 584, 141 A.2d 308, 311 (1958).

Indian Towing Co. v. United States, 350 U.S. 61, 65 (1955).

- Id., quoted in Owen v. City of Independence, $100 \mathrm{~S}$. Ct. 1398, 1412 n.26 (1980).

- Elgin v. District of Columbia, 337 F.2d 152, 156 (D.C. Cir. 1964).

- Employees of the Dep't of Pub. Health \& Welfare v. Department of Pub. Health \& Welfare, 411 U.S. 279, 297 n.11 (1973) (Marshall, J., concurring).

- 3 K. Davis, Administrative Law Treatise $§ 25.07$, at 460 (1958).

' See Tribe, Unraveling National League of Cities: The New Federalism and Affirmative Rights to Essential Government Services, 90 Harv. L. Rzv. 1065, 1072 n.34 (1977).

- See D. Currie, Federal Courts, Cases and Materials 565 (2d ed. 1975); Stone, Restrictions of Speech Because of its Content: The Peculiar Case of Subject-Matter Restrictions, 46 U. CHI. L. Rzv. 81, 91 (1978) [hereinafter cited as Restrictions of Speech]. Professor Stone has acknowledged the relevance of the distinction in some constitutional cases. See Stone, Fora Americana: Speech in Public Places, 1974 Sup. Cr. Rzv. 233, 276 n.161 [hereinafter cited as Fora Americana].

- The distinction persists in the following areas of the law:

(1) municipal tort liability, see W. Prosser, HandbooK of THE LAw of TorTs § 131, at 977-87 (4th ed. 1971);

(2) several constitutional contexts discussed at notes 151-60 infra and accompanying text;

(3) immunity of foreign sovereigns, see 28 U.S.C. $\$ \S 1330,1602-1611$ (1976) (amending 28 U.S.C. $\$ \S 1332,1391,1441$ (1976)), discussed in East Europe Domestic Int'l Sales Corp. v. Terra, 467 F. Supp. 383, 386-87 (S.D.N.Y. 1979);

(4) common-law sovereign immunity, see Teague v. Grand River Dam Auth., 425 F.2d 130, 132 (10th Cir. 1970); Lykins v. Peoples Community Hosp., 355 F. Supp. 52, 53 (E.D. 
The United States Supreme Court itself appears ambivalent about its worth. In some cases, the Court has rejected the distinction and has directed scathing criticism toward it; ${ }^{10}$ but the Court also has found the distinction useful for a variety of purposes. In recent

Mich. 1973);

(5) construction of federal statutes to determine whether the government has waived its immunity, see, e.g., FHA v. Burr, 309 U.S. 242, 245 (1940); Beneficial Fin. Co. v. Dallas, 571 F.2d 125, 127-28 (2d Cir. 1978);

(6) determination of whether equitable estoppel may be applied against the government, see, e.g., United States v. Lazy FC Rancb, 481 F.2d 985, 989 (9th Cir. 1973); Hicks v. Califano, 450 F. Supp. 278, 282-83 (N.D. Ga. 1977); but see United States v. Bailey, 467 F. Supp. 925, 930-31 (E.D. Ark. 1979) (rejecting these "traditional pigeonholes");

(7) application of the Convention on Recognition and Enforcement of Arbitral Awards, see Island Territory of Curacao v. Solitron Devices, Inc., 489 F.2d 1313, 1317 (2d Cir. 1973) (dicta), cert. denied, 416 U.S. 986 (1974);

(8) application of state statutes of limitations to the federal government, see United States v. Essley, 284 F.2d 518, 521 (10th Cir. 1960);

(9) determination of whether a foreign businessman in the United States for dealings with the government may be served with process, see Ramamurti v. Rolls-Royce, Ltd., 454 F. Supp. 407, 411 (D.D.C. 1978);

(10) the scope of the federal common law, see United States v. Kimbell Foods, Inc., 440 U.S. 715, 733-38 (1979); but cf. Mishkin, The Variousness of "Federal Law": Competence and Discretion in the Choice of National and State Rules for Decision, 105 U. PA. L. Rev. 797, 797 n.3 (1957) ("Analytically, the problem breaks down along the same basic lines whether the government activity to which the particular issue is related is of a 'regulatory' nature or is more a 'corporate' operation.");

(11) the assertion of constitutional rights against the states by the federal government acting in a proprietary capacity, see United States v. Public Serv. Comm'n, 422 F. Supp. 676,682 (D. Md. 1976) (concurring opinion).

This list is intended to give an idea of the breadth of the distinction's application and is not exhaustive.

One constitutional context in which the courts use the distinction but which this article does not examine is the determination of whether wholly private activity may be deemed state action for purposes of the fourteenth amendment. At times the Court has drawn a distinction between customarily private and public activity in determining whether the actions of a private party are actions of the state. See Jackson v. Metropolitan Edison Co., 419 U.S. 345, 352-53 (1974) ("We have, of course, found state action present in the exercise by a private entity of powers traditionally exclusively reserved to the State.") (citing cases concerning elections, company towns, and city parks but holding that a private utility is not a state actor). In its most recent decision in this area, however, the Court has held that even such a traditionally governmental activity as a sheriff's sale of goods to satisfy a hen does not become state action when committed to a private party. See Flagg Bros. v. Brooks, 436 U.S. 149, 158 (1978) ("While many functions have been traditionally performed by governments, very few have been 'exclusively reserved to the State." "). Only where the state permits private parties to perform "exclusive public function[s]" will state action be found. Id. at 161.

${ }^{10}$ See, e.g., Rayonier, Inc. v. United States, 352 U.S. 315, 319 (1957); Indian Towing Co. v. United States, 350 U.S. 61, 65 (1955); City of Trenton v. New Jersey, 262 U.S. 182, 192 (1923). 
years, the distinction has appeared in Supreme Court opinions concerning the sovereign immunity of foreign nations for their acts of state, ${ }^{11}$ the application of the antitrust laws to state and local governments, ${ }^{12}$ the negative implications of the commerce clause ${ }^{13}$ (and perhaps the affirmative powers of Congress under that clause $^{14}$ ), the scope of state immunity from suit under the eleventh amendment, ${ }^{15}$ and the constitutional rights of individuals against the state. ${ }^{16}$ The distinction's persistence in the face of unrelenting criticism raises the question whether it may be a more subtle and intelligible doctrine than its reputation would suggest. This article pursues that question with respect to the uses to which the Court has put the distinction in constitutional cases. In view of the confusion surrounding the distinction, it is useful to begin the inquiry by mapping the ground that will be covered.

\section{The Distinction}

The governmental-proprietary distinction is neither a single nor a simple rule. Rather, it is a cluster of rules that courts use in diverse contexts for a variety of purposes. In constitutional cases, courts use the governmental-proprietary distinction to aid in the resolution of two types of problems: First, whether to deny a state an immunity that it might otherwise enjoy; and, second, whether to free a state from a constitutional constraint that might otherwise limit its action.

The first category includes cases that raise governmental immunity issues under the eleventh amendment's bar to suits against states in federal courts by individuals and under the implied immunity the states enjoy from federal taxation and regulation. Courts in these cases have articulated a governmental-proprietary

11 See Alfred Dunhill, Inc. v. Republic of Cuba, 425 U.S. 682 (1976) (plurality opinion).

13 See City of Lafayette v. Louisiana Power \& Light Co., 435 U.S. 389, 418-26 (1978) (Burger, C.J., concurring). See also Star Lines, Ltd. v. Puerto Rico Maritime Shipping Auth., 451 F. Supp. 157, 162-66 (S.D.N.Y. 1978); Note, Antitrust Law-Municipal Immunity-Application of the State Action Doctrine to Municipalities, 1979 WIs. L. REv. 570, 596-603.

1s See Hughes v. Alexandria Scrap Corp., 426 U.S. 794 (1976).

14 See National League of Cities v. Usery, 426 U.S. 833 (1976).

18 See Parden v. Terminal Ry., 377 U.S. 184 (1964).

16 See Lehman v. City of Shaker Heights, 418 U.S. 298, 303-04 (1974) (plurality opinion); Pickering v. Board of Educ., 391 U.S. 563, 568 (1968); Cafeteria Workers Local 473 v. McElroy, 367 U.S. 886, 896 (1961). 
distinction grounded in the importance or the customary nature of state activity. Courts have deemed traditional or essential state functions governmental and therefore immune from federal taxation and regulation or private lawsuits. While the distinction once played a critical role in the dehneation of state immunity from federal taxation, the courts ultimately abandoned it as a tool of constitutional analysis in this area. With regard to state immunity from federal regulation, however, there are suggestions that the distinction has been revived recently. Eleventh amendment law is presently in disarray, and few generalizations can be made with confidence. It may be observed, however, that the governmentalproprietary distinction has informed eleventh amendment law for most of the amendment's history, and recent cases indicate that its role may be expanding.

A more precise governmental-proprietary distinction has emerged in the second category of cases involving the applicability of constitutional limitations to state activities. In defining the constitutional rights of individuals against the state, courts relying on the governmental-proprietary distinction have permitted states a freer hand where they act as employers, landlords, purchasers, sellers, and the hike, than when they regulate the citizenry in general. Similarly, in delimiting the restraints imposed on the states by the negative imphications of the commerce clause, courts have invoked the governmental-proprietary distinction to accord the states greater latitude when they act as participants in markets than when they regulate private businesses.

Just as the nature of the distinction varies depending on the context in which it is used, so do the purposes for which it is invoked. The diversity of purposes, however, is more complicated than the two basic variations of the distinction might suggest, and courts often have failed to articulate these purposes clearly. The distinction used in the commerce clause and constitutional rights contexts is roughly the same, but the purposes for which it is drawn and the implications of its invocation differ. In commerce clause cases, it may serve to identify cases where the effect of a state's activity on commerce is too slight to warrant review under the negative implications of that clause. ${ }^{17}$ Alternatively, it may mark out an area of state autonomy that lies beyond the reach of

${ }^{17}$ See notes 211-17 infra and accompanying text. 
the commerce clause standing alone. ${ }^{18}$ By contrast, when the issue is the scope of an individual's constitutional rights against a state employer, contractor, or landlord, the distinction legitimately serves only to identify a state interest not present when the state regulates the general public. It should be but one element in the analysis and should not by itself determine the outcome. ${ }^{19}$

A similar variety of purposes exists in the different immunity contexts. In each of these areas, the distinction has been a tool for accommodating the state's interest in immunity with the competing federal interest in taxation or regulation, or the individual's interest in pursuing a remedy for the state's perceived breach of duty. The state's immunity claim, however, is not equally strong in all three areas. In particular, the state's immunity defense proves most persuasive in the eleventh amendment context, where the state challenges only the bringing of lawsuits by individuals and not the existence of congressional power to regulate or tax. Accordingly, it is hardly surprising that the courts have characterized as proprietary and thus outside the pale of the immunity a broad range of the states' activities in the regulation and taxation contexts.

The courts' failure to articulate carefully the purposes for making governmental-proprietary distinctions, combined with the widespread use of governmental-proprietary distinctions outside the constitutional context, has led to considerable confusion in the cases and criticism of the distinction from judges and academics. ${ }^{20}$

\footnotetext{
18 See notes 218-44 infra and accompanying text.

19 See notes 173-83 infra and accompanying text.

${ }^{20}$ No necessary connection exists, for example, between the common-law rule that immunizes municipalities from tort liability when they are acting in their governmental as distinguished from their proprietary capacities, and the eleventh amendment principle that a state's governmental activity receives more protection from individual suit than does its proprietary activity. The preservation of state autonomy and the protection of federal rights should weigh heavily in defining the scope of the terms "governmental" and "proprietary" in the eleventh amendment context, but are not relevant to common-law sovereign immunity decisions. Courts in eleventh amendment cases, however, sometimes rely on commonlaw sovereign immunity rules, and scholars sometimes imply that the two distinctions are one. See, e.g., Skehan v. Trustees of Bloomsburg State College, 538 F.2d 53, 62 (3d Cir.) (by implication), cert. denied, 429 U.S. 979 (1976); Whitten v. State Univ. Constr. Fund, 493 F.2d 177, 179-80 (1st Cir. 1974); Bagrowski v. American Export Isbrandtsen Lines, Inc., 440 F.2d 502, 509 (7th Cir. 1971); Clifton v. Grisham, 381 F. Supp. 324, 326 (N.D. Miss. 1974); D. CuRrIE, supra note 8, at 565; Carrow, Sovereign Immunity in Administrative Law-A New Diagnosis, 9 J. PuB. L. 1, 18-19 (1960).
} 
The aims of this article are to show that the content of the terms governmental and proprietary must be fashioned to fit the purposes for which they are employed in particular contexts, to identify the constitutional contexts in which the distinction is invoked and the purposes it serves in each of those contexts, and to elucidate the content that is and should be given the distinction in each context to serve each purpose.

\section{IMMUNITIES}

\section{A. Intergovernmental Immunities}

The doctrine that the federal and state governments enjoy some immunity from each other's powers to tax and regulate has been a persistent theme in American constitutional adjudication. The federal government's immunity is rooted both in the supremacy clause and in implications that the Court has drawn from the constitutional scheme itself; ${ }^{21}$ the states' immunity derives entirely from these implications, ${ }^{22}$ unless one reads the tenth amendment as adding something to them. ${ }^{2 s}$ The Court construed both the federal government's immunity from state legislation and the state governments' immunity from federal legislation expansively during the early period of their development, ${ }^{24}$ when the principle of intergovernmental immunity was regarded as an absolute prohibition on taxation or regulation of one government by the other. ${ }^{25}$ Subsequently, there was a dramatic retrenchment in the scope of both federal and state immunities ${ }^{28}$ when the practical consequences of

21 See McCulloch v. Maryland, 17 U.S. (4 Wheat.) 316 (1819); C. Black, Structure AND Relationship in Constitutional Law 15 (1969).

${ }^{22}$ See Collector v. Day, 78 U.S. (11 Wall.) 113 (1870).

${ }^{23}$ See National League of Cities v. Usery, 426 U.S. 833 (1976).

${ }^{24}$ See, e.g., Collector v. Day, 78 U.S. (11 Wall.) 113 (1870) (federal income tax on state employee unconstitutional), overruled by Graves v. New York ex rel. O'Keefe, 306 U.S. 466 (1939); Dobbins v. Commissioners of Erie County, 41 U.S. (16 Pet.) 435 (1842) (state income tax on federal employee unconstitutional).

${ }^{26}$ See Comment, Federal Immunity from State Taxation: A Reassessment, 45 U. CHI. L. REv. 695, 696-700, 708 (1978). The classic treatments of the doctrine remain Powell, The Waning of Intergovernmental Tax Immunities, 58 HARv. L. REv. 633 (1945) [hereinafter cited as The Waning of Immunities]; and Powell, The Remnant of Intergovernmental Tax Immunities, 58 HaRv. L. Rev. 757 (1945).

${ }^{28}$ See, e.g., Graves v. New York ex rel. O'Keefe, 306 U.S. 466 (1939) (state income tax on federal employee constitutional); Helvering v. Gerhardt, 304 U.S. 405 (1938) (federal income tax on state employee constitutional). The O'Keefe case explicitly repudiated the decisions 
such a sweeping doctrine were brought to bear on the determination of whether immunity ought to be recognized. ${ }^{27}$

Despite the parallels in the evolution of federal and state immunities from each other's taxing and regulatory powers-indeed, at one time, the immunities were regarded as reciprocal ${ }^{28}$ - there are substantial differences in the considerations relevant to their respective applications. First, as Chief Justice Marshall observed in McCulloch v. Maryland, ${ }^{29}$ there is

[t]he difference ... which always exists, and always must exist, between the action of the whole on a part, and the action of a part on the whole-between the laws of a government declared to be supreme, and those of a government which, when in opposition to those laws, is not supreme. ${ }^{30}$

Second, there is an inherent "pohtical check"31 on federal legislation that does not operate to confine state legislation. Because the people of all the states are represented in Congress, federal legislation in derogation of state interests is unlikely; because the federal government is not represented in state legislatures, no comparable political restraint keeps states from enacting legislation in derogation of federal interests. Third, the federal government possesses power under the supremacy clause to immunize itself or its instrumentalities from unfriendly state legislation by explicitly so providing; ${ }^{32}$ the states possess no such power to inhibit the reach of federal legislation. These differences have been reflected, especially in recent years, in judicial opinions that have examined the scope and purposes of the federal and state governments' immunities from each other's legislation. ${ }^{33}$

cited in note 24 supra. See 306 U.S. at 481-87.

27 See New York v. United States, 326 U.S. 572, 577-78 (1946) (Frankfurter, J., announcing the judgment without plurality); Graves v. New York ex rel. O'Keefe, 306 U.S. 466, 483 (1939).

${ }^{28}$ See New York v. United States, 326 U.S. 572, 576 (1946) (Frankfurter, J., announcing the judgment without plurality).

20 17 U.S. (4 Wheat.) 316 (1819).

so Id. at $435-36$.

${ }^{31}$ United States v. County of Fresno, 429 U.S. 452, 458 (1977). See also Helvering v. Gerhardt, 304 U.S. 405, 412 (1938); McCulloch v. Maryland, 17 U.S. (4 Wheat.) 316, 435-36 (1819).

${ }^{32}$ See, e.g., Federal Land Bank v. Bismarck Lumber Co., 314 U.S. 95, 101-04 (1941).

ss See Massachusetts v. United States, 435 U.S. 444 (1978); United States v. County of Fresno, 429 U.S. 452 (1977). 
It is against this background that the function served by the governmental-proprietary distimction in the delineation of these immunities can be examined. For many years, the distinction was invoked as a critical determinant of the scope of state immunity from federal taxation. If Congress imposed a tax on a state's governmental activities, it would violate the state's constitutional immunity; ${ }^{34}$ if the tax fell on the state's proprietary activities, however, the immunity claim would fail. ${ }^{35}$ The distinction has also surfaced recently in connection with the states' immunity from federal regulation under the commerce clause, which the Court recognized in National League of Cities $v$. Usery. ${ }^{36}$ Whatever may be the core of state activities protected from congressional intrusion under that decision, they do not embrace the states' proprietary activities. ${ }^{37}$ By contrast, the distinction has played virtually no role in limiting the federal government's immunity from state legislation. The Court has gone so far as to declare that

every action [of the federal government] within its constitutional power is governmental action, and since Congress is made the sole judge of what powers within the constitutional grant are to he exercised, all activities of the government constitutionally authorized by Congress must stand on a parity with respect to their constitutional immunity from taxation. ${ }^{38}$

\section{State Immunity from Federal Taxation}

An inquiry into the content and function of the governmentalproprietary distinction in state tax immunity law must begin by identifying the purposes underlying the constitutional restrictions on federal taxation of the states. Only then can it be determined how the distinction may serve these purposes and what are the appropriate criteria for drawing the distmction with those purposes in mind. The premises underlying judicial recognition of the states' immunity from federal taxation were first set forth in Collector $v$.

34 See, e.g., Indian Motorcycle Co. v. United States, 283 U.S. 570, 575-76 (1931).

ss See, e.g., Ohio v. Helvering, 292 U.S. 360, 368-69 (1934).

36 426 U.S. 833 (1976).

${ }^{37}$ See id. at 854 n.18.

38 Graves v. New York ex rel. O'Keefe, 306 U.S. 466, 477 (1939). See also Federal Land Bank v. Bismark Lumber Co., 314 U.S. 95, 102 (1941). Cf. Mayo v. United States, 319 U.S. 441 (1943) (United States acts in "governmental" capacity when distributing commercial fertilizer pursuant to national soil conservation program). 
Day. ${ }^{39}$ In holding unconstitutional the application of a federal income tax to a state judge's salary, the Court declared that in light of

the separate and independent condition of the States in our complex system, as recognized by the Constitution, . . . it would seem to follow, as a reasonable, if not a necessary consequence, that the means and instrumentalities employed for carrying on the operations of their governments, for preserving their existence, and fulfilling the high and responsible duties assigned to them in the Constitution, should be left free and unimpaired, should not be liable to be crippled, much less defeated by the taxing power of another government, which power acknowledges no limits but the will of the legislative body imposing the tax..0

The difficulties spawned by this doctrine have not been attributable to any disagreement about the legitimacy of the basic purpose that the immunity serves: to prevent the federal government from obstructing the operation of state governments. Indeed, despite narrowing the scope of states' immunity and overruling Collector $v$. Day itself, ${ }^{41}$ the Court continues to recognize this central purpose as the predicate of the imphed constitutional restriction on the national taxing power. ${ }^{42}$

The difficulties created by the doctrine of state immunity from federal taxation have instead been attributable to its potentially unlimited scope. A doctrine that justified the immunization of a state judge's salary from federal taxation because the congressional taxing power might cripple the operations of state government could also have been invoked to immunize from federal taxation income derived by private parties from state and local bonds (so as not to impair the states' ability to borrow money) ${ }^{43}$ or from lands leased from the state (so as not to impair the states' ability to utilize the public domain). ${ }^{44}$ It was due to tle Court's recognition of

30 78 U.S. (11 Wall.) 113 (1870), overruled by Graves v. New York ex rel. O'Keefe, 306 U.S. 466 (1939).

40 Id. at $125-26$.

${ }^{41}$ See Graves v. New York ex rel. O'Keefe, 306 U.S. 466, 481-87 (1939).

12 See Massachusetts v. United States, 435 U.S. 444, 459 (1978); New York v. United States, 326 U.S. 572, 576 (1946) (Frankfurter, J., announcing the judgment without plurality).

${ }^{43}$ See Pollock v. Farmers' Loan \& Trust Co., 157 U.S. 429, 583-86 (1895).

"See Burnet v. Coronado Oil \& Gas Co., 285 U.S. 393 (1932). 
the potential sweep of this doctrine, and in particular its consequences for the taxing powers of the federal government, that the governmental-proprietary distinction emerged as a limiting principle.

In South Carolina v. United States, ${ }^{45}$ the Court confronted the question whether Congress could impose a federal liquor license tax on "agents of a State which, in the exercise of its sovereign power, lias taken cliarge of the business of selling intoxicating liquors." ${ }^{48}$ The Court acknowledged the force of the argument, predicated on Collector $v$. Day, that permitting Congress to tax the state liquor authority could lead to the destruction of the state's legitimate effort to exercise its police power to control the sale of liquor. ${ }^{47}$ The Court, however, went on to consider tlie consequences of the state's assuming, under its police power, the sale of tobacco, margarine, and all other objects of the (tlien-limited) internal revenue tax:

Obviously, if the power of the State is carried to the extent suggested, and with it is relief from all Federal taxation, the National Government would be largely crippled in its revenues. . . .

There is something of a conflict between the full power of the Nation in respect to taxation and the exemption of the State from Federal taxation in respect to its property and a discharge of all its functions. Where and how shall the line between them be drawn?t8

After discussing the limited powers of government as conceived when the Constitution was written and surveying tax immunity cases that emphasized the governmental nature of the exempted activities, the Court concluded that the answer lay in the distinction between a state's governmental and proprietary functions. Drawing primarily on the body of case law that liad developed the governmental-proprietary distinction in connection with the power and liability of municipal corporations, the Court, without considering whether the purposes for which the distinction had been so employed were germane to those it was now called upon to serve, declared:

\footnotetext{
199 U.S. 437 (1905).

16 Id. at 447.

17 See id. at 453-54.

18 Id. at 455-56.
} 
Now, if it be well established, as these authorities say, that there is a clear distinction as respects responsibility for negligence between the powers granted to a corporation for governmental purposes and those in aid of private business, a like distinction may be recognized when we are asked to limit the full power of imposing excises granted to the National Government by an implied inability to impede or embarrass a State in the discharge of its functions. It is reasonable to hold that while the former may do nothing by taxation in any form to prevent the full discharge by the latter of its governmental functions, yet whenever a State engages in a business which is of a private nature that business is not withdrawn from the taxing power of the Nation. ${ }^{9}$

What is striking about the Court's adoption of the governmental-proprietary distinction as a means of confining the state's immunity from federal taxation is that, from the very beginning, the content of the distinction was virtually irrelevant. The Court simply wanted to draw a line circumscribing the scope of a potentially unlimited immunity. It gave no explicit attention to whetlier the line so drawn reflected the purposes for which the immunity was recognized in the first place. ${ }^{50}$ Indeed, the Court made no effort to justify its invocation of the governmental-proprietary distinction on substantive grounds, even though the dissent noted that the governmental-proprietary distinction was marked by "confusion and contradiction."

Subsequent developments support the hypothesis that the governmental-proprietary distinction had no solid analytical justification in this context nor any content independent of that given to it by later cases. As an instrnment for curtailing the scope of the state's immunity from federal taxation, it was employed to deny immunity to the income of state-operated street railways' trustees, ${ }^{52}$ to the income of state-appointed liquidators of insolvent cor-

49 Id. at 463 .

Bo The Court sometimes has refused to import the governmental-proprietary distinction into constitutional analysis when the purposes for which the Court uses the distinction in municipal corporations law have no relationship to the purposes of the constitutional inquiry. See City of Trenton v. New Jersey, 262 U.S. 182, 192 (1923) (governmental-proprietary distinction affords no basis for city, allegedly acting in proprietary capacity, to assert contract clause or due process claims against state).

b1 199 U.S. at 471.

B2 See Helvering v. Powers, 293 U.S. 217 (1934). 
porations, ${ }^{53}$ and to the receipts from admissions to football games sponsored by state instrumentalities, ${ }^{54}$ but not to the income of a city waterworks employee..$^{55}$ Efforts to sort out the cases on the basis of a principled distinction between governmental and proprietary activities have not been rewarding, ${ }^{56}$ for the Court's decisions were motivated not by a perceived difference between a state's governmental and proprietary activities but rather by a distinction between activities the Court regarded as sufficiently important to the states' identity to warrant restriction of the federal taxing power and those not so regarded..$^{\text {s7 }}$

The distinction's lack of a firm foundation in the purposes behind state tax immunity also explains why the Court ultimately could abandon the distinction with such equanimity ${ }^{58}$ and, in so doing, leave the body of precedent it had created substantially undisturbed. In New York v. United States, ${ }^{59}$ the Court recognized that the governmental-proprietary distinction did "not furnish a satisfactory guide for dealing with such a practical problem as the constitutional power of the United States over State activities"60 and that it was "too shifting a basis for determining constitutional power and too entangled in expediency to serve as a dependable legal criterion." The Court instead adopted a more candid approach to the resolution of the conflict between state and national interests. The Court considered such factors as whether the federal tax discriminated against the states;" whether it taxed the "State

\footnotetext{
s3 See Helvering v. Therrell, 303 U.S. 218 (1938).

b4 See Allen v. Regents of the Univ. System of Ga., 304 U.S. 439 (1938).

ss See Brush v. Commissioner, 300 U.S. 352 (1937).

so See generally The Waning of Immunities, note 25 supra. See also Rakestraw, The Reciprocal Rule of Tax Immunity-A Legal Myth, 11 FED. B.J. 3, 31 (1950).

${ }^{87}$ See New York v. United States, 326 U.S. 572 (1946); notes 59-66 infra and accompanying text.

${ }^{88}$ See note 60 infra.

so 326 U.S. 572 (1946).

so Id. at 580 (Frankfurter, J., announcing the judgment without plurality). Although the
} Court did not have an opinion in the case, "[a]ll eight Justices who participated in the case indicated that they regarded the governmental-proprietary distinction as an untenable one." Massachusetts v. United States, 435 U.S. 444, 457 n.14 (1978) (citing New York v. United States, 326 U.S. at 579-81 (Frankfurter, J., joined by Rutlege, J.); id. at 586 (Stone, C.J., concurring in the judgment, joined by Reed, Murphy \& Burton, JJ.); and id. at 591 (Douglas, J., dissenting, joined by Black, J.)).

31326 U.S. at 580 (Frankfurter, J., announcing the judgment without plurality).

${ }_{62}$ Id. at 583-84 (Frankfurter, J., announcing the judgment without plurality); id. at 586 (Stone, C.J., concurring in the judgment). 
as a State," ${ }^{\text {Bs }}$ as would, for example, a tax on a state's statehouse or its tax revenue; and the extent to which recognition of the immunity would withdraw property or activities from federal taxation. ${ }^{64}$ In so doing, the Court openly confronted the task of accommodating the state interest in autonomy and the countervailing national interests in order to determine whether a federal tax amounted to an "undue interference" though the cases ultimately might turn on little more than what five Justices viewed as undue interference, the determination would no longer be hampered by the "rhetorical absolute"se of immunity embodied in Collector $v$. Day. The governmental-proprietary distinction had, of course, allowed the Court to balance these interests all along, but without openly explaining how it had reached an accommodation between two constitutional facts that are not always compatible: the existence of federal taxing power and the existence of the states. Since the distinction stood for little more than the line the Court had drawn on other, unarticulated grounds, the distinction could be painlessly discarded once the actual grounds themselves were revealed.

\section{State Immunity from Federal Regulation}

The rise and fall of the governmental-proprietary distinction as a tool of constitutional analysis in connection with state immunity from federal taxation throws some light on its function in the context of state immunity from federal regulation, where it arguably has been resurrected in National League of Cities $v$. Usery. ${ }^{67}$ Drawing in part on the principles developed in the tax immunity cases, the Court struck down the application of the Fair Labor Standards Act's minimum wages and maximum hours provisions to state and local governments and held that Congress could not exercise its power under the commerce clause "to directly displace the States' freedom to structure integral operations in areas of tradi-

62 Id. at 582 (Frankfurter, J., announcing the judgment without plurality); id. at 587-88 (Stone, C.J., concurring in the judgment).

ot Id. at 590 (Stone, C.J., concurring).

(s Massachusetts v. United States, 435 U.S. 444, 459 (1978).

“ New York v. United States, 326 U.S. 572, 576 (1946) (Frankfurter, J., announcing the judgment without plurality).

426 U.S. 833 (1976). 
tional governmental functions." In repudiating dicta from United States v. California ${ }^{68}$ that the restrictions on the federal taxing power over the states were not relevant to restrictions on the federal commerce power over them, the Court found the holding of the earlier case, which sustained the exercise of congressional power, consistent with its holding in National League of Cities: "[In United States v. California,] activity to which the congressional command was directed was not in an area that the States have regarded as integral parts of their governmental activities. It was, on the contrary, the operation of a railroad engaged in 'common carriage by rail in interstate commerce . . . " "ro

Although some observers have read this comment as foretelling a "revival" of the governmental-proprietary distinction for purposes of analyzing state immunity from federal legislation under the commerce clause, ${ }^{71}$ reference to the Court's experience with the distinction in the tax immunity context suggests that such a reading is not warranted. The distimction emerged in the tax cases as a means of confining the scope of state immunity, and the distinction itself bore no intrinsic relationship to the purposes underlying recognition of the immunity. The distinction bears no more meaningful relationship to the purposes underlying the states' immunity from federal commerce power-protecting the states' independent role in the federal system ${ }^{72}$-than to the virtually identical purposes underlying the states' immunity from federal tax power.

Moreover, in striking contrast to the circumstances surrounding the adoption of the governmental-proprietary distinction in the tax immunity cases, the Court has no pressing need for an instrument to limit the states' immunity from congressional commerce power. Indeed, prior to 1976, one might reasonably have thought that no such immunity even existed..$^{73}$ Furthermore, the Court in National League of Cities demonstrated its willingness to identify specifically the aspects of state sovereignty that require protection from

68 Id, at 852 .

69297 U.S. 175 (1936).

70 426 U.S. at 854 n.18.

7 See J. Nowak, R. Rotunda \& J. Young, Handbook on Constitutional Law 161 (1978).

See also Tribe, supra note 7 , at 1072-75.

72 See National League of Cities v. Usery, 426 U.S. 833, 844-46 (1976).

${ }_{73}$ See id. at 856-80 (Brennan, J., dissenting). 
the exercise of congressional commerce power; ${ }^{74}$ the courts in the tax immunity cases used the distinction for the very purpose of avoiding an exphicit accommodation of state and federal interests. In short, since the conditions that nurtured the development of the governmental-proprietary distinction in the context of state immunity from the federal taxing power are absent in the context of state immunity from the federal commerce power, it is unlikely that National League of Cities signals a revival of the distinction in the delineation of the latter immunity. ${ }^{75}$

\section{Federal Immunity from State Taxation and Regulation}

Despite the once prevailing view that the federal and state immunity doctrines are reciprocal, ${ }^{78}$ the governmental-proprietary distinction never emerged as a decisional principle with regard to federal immunity from state taxation and regulation. The federal immunity context, however, presents conditions identified above as conducive to its adoption: Justice Marshall's "rhetorical absolute"77 - the power to tax involves the power to destroy"8 - laid the

74 This is not to suggest, however, that the Court necessarily was successful in identifying the elements of state sovereignty that warranted protection from such power. Arguably, the notions of "integral," "traditional," or "essential" governmental functions central to the states' "separate" or "independent" existence in the federal system, National League of Cities v. Usery, 426 U.S. 833 passim (1976), defy rational analysis. See Michelman, States' Rights and States' Roles: Permutations of Sovereignty in National League of Cities v. Usery, 86 YALE L.J. 1165 (1977); Tribe, note 7 supra. Our point here, however, is only that the Court in National League of Cities attempted squarely to confront the difficult problems of accommodation hetween state and national interests, thereby obviating recourse to the governmental-proprietary distinction as a mechanism for doing the same thing.

${ }^{75}$ We do not mean to imply that courts will never invoke the governmental-proprietary distinction in this context, but rather that the courts' inquiry will likely center on whether federal legislation "directly displace[s] the States' freedom to structure integral operations in areas of traditional governmental functions," 426 U.S. at 852, and not on whether the regulated activity can be characterized as proprietary. To be sure, however, traditional commercial activities that the courts have characterized as proprietary in the past may well fall outside the core of state activities protected by National League of Cities. See Public Serv. Co. v. Federal Energy Regulatory Comm'n, 587 F.2d 716, 721 (5th Cir.) (state's oil and gas business "indistinguishable from like commercial activities of private business" and not a "traditional governmental function" within the meaning of National League of Cities), cert. denied sub nom. Louisiana v. Federal Energy Regulatory Comm'n, 100 S. Ct. 166 (1979).

76 See note 28 supra and accompanying text.

77 See note 66 supra and accompanying text.

76 McCulloch v. Maryland, 17 U.S. (4 Wheat.) 316, 431 (1819). Although McCulloch involved the exercise of state taxing power, its reasoning has been held equally applicable to 
cornerstone for federal immunity and admitted of no limiting principle. Moreover, before the late 1930's, the Court was no more inclined to confront directly the difficult problems of accommodation with regard to federal immunity than it was with regard to state immunity. ${ }^{79}$ Nevertheless, the Court consistently has refused to apply the governmental-proprietary distinction to the federal immunity cases on the ground that "[t]he federal government is one of delegated powers, and from that it necessarily follows that any constitutional exercise of its delegated powers is governmental."80 As Thomas Reed Powell has pointed out, however, this explanation is unsatisfactory:

We may agree that action by the nation within its powers is governmental action, but some of governmental action may be also business activity. The fact that the nation may do only what it may do does not inean that none of the things that it may do can be business activity. The fact that the scope of national action is restricted by a written constitution in no way prevents a ruling that when the United States elects "to support a governmental activity through the conduct of a busmess comparable in all essentials to those usually conducted by private owners," such business is not thereby withdrawn from state taxation. ${ }^{81}$

Nor can one contend that the Court has not in fact substantially limited the federal government's immunity from state legislation over the years; from the mid-nineteenth century to the present day, the Court has rehed on a variety of doctrines to circumscribe the scope of federal immunity. ${ }^{82}$

The explanation for the absence of the governmental-proprietary distinction in the federal immunity context would seem to lie in a

the exercise of state regulatory power. See, e.g., Johnson v. Maryland, 254 U.S. 51, 55-56 (1920). Indeed, the Court generally has made no distinction between the constitutional principles governing state taxation and state regulation of the federal government. See, e.g., Mayo v. United States, 319 U.S. 441 (1943) (citing numerous tax cases in holding United States immune from state regulation). Cases involving state taxation of the federal government, however, are far more numerous than those involving state regulation of the federal government.

70 See Comment, supra note 25, at 696-700.

so Federal Land Bank v. Bisinarck Lumber Co., 314 U.S. 95, 102 (1941). See also Graves v. New York ex rel. O'Keefe, 306 U.S. 466, 477 (1939).

81 The Waning of Immunities, supra note 25, at 651 (quoting Allen v. Regents of the Univ. System of Ga., 304 U.S. 439, 451 (1938)).

${ }^{82}$ See Comment, supra note 25 , at 700-07. While the authority cited discusses only state taxation, the same conclusions can be drawn in the state regulation context. See L. TriBE, American Constitutional LaW 391-94 (1978); note 78 supra. 
number of considerations. First, the position of the states vis-à-vis the federal government differs from the position of the federal government vis-à-vis the states. ${ }^{83}$ The federal government's supremacy and the lack of "political checks" on state legislation might justify greater protection for federal interests. Introduction of an easily manipulated criterion like the governmental-proprietary distinction into the federal immunity context might in the Court's view have subjected the federal government to too great a risk that its functions would be hampered by undue interference from hostile state legislation. ${ }^{84}$ Second, the Court may have chosen to defer to Congress's power to expand or waive federal immunity through legislation, ${ }^{85}$ thus avoiding substantial judicial entanglement with the dehineation of the immunity that adoption of a decisional tool hike the governmental-proprietary distinction would no doubt have ensured. Finally, as should be implicit from what has already been said, there was nothing about the distinction to compel its use as a limiting principle. While it proved useful for the Court in the state immunity context and might well have served similar purposes in the federal immunity context, perhaps the essential characteristics of the distinction are its malleability and dispensability: within the realm of its application there seems to be virtually no purpose it cannot be made to serve nor any purpose that cannot be served as well by other means.

\section{B. Immunity Under The Eleventh Amendment}

An individual may not sue a state in federal court without the state's consent. ${ }^{86}$ Because this immunity often leaves individuals

see notes 29-33 supra and accompanying text.

s Indeed, the United States specifically has warned the Court against adopting the governmental-proprietary distinction as a limitation of federal immunity for precisely this reason. See Brief for United States as amicus curiae at 24-25, Graves v. New York ex rel. O'Keefe, 306 U.S. 466 (1939). See also The Waning of Immunities, supra note 25, at 654-55 $\&$ n.83. Although the Court has rejected the governmental-proprietary distinction with regard to constitutional immunities of the federal government, it has used the distinction in construing federal statutes to determine whether Congress intended to permit suits thereunder against the government. See FHA v. Burr, 309 U.S. 242, 245 (1940); Keifer \& Keifer v. Reconstruction Fin. Corp., 306 U.S. 381, 388-96 (1939). See also Beneficial Fin. Co. v. Dallas, 571 F.2d 125, 127-28 (2d Cir. 1978); Peter J. Statile Assoc., Inc. v. Panama Canal Co., 441 F. Supp. 160, 162 n.3 (D.D.C. 1977).

see The Waning of Immunities, supra note 25, at 655-56.

* U.S. Const. amend. XI. By its terms, the eleventh amendment applies only to suits 
without a remedy against states' breaches of legal duties, it has faced strong oppostion ever since its inception ${ }^{87}$ and has never been an absolute bar to suits against the states'in federal court. The governmental-proprietary distinction is one of the devices courts have used to limit the eleventh amendment immunity, by making it harder for the state to sustain an immunity claim when the activity giving rise to the lawsuit is characterized as proprietary rather than governmental. ${ }^{88}$

Although courts have often used the governmental-proprietary distinction in resolving eleventh amendment issues, they have never provided a reasoned explanation of its place in eleventh amendment law. An examination of the cases suggests that courts use the distinction in this context in one of two ways, each corresponding to a different view of the amendment itself. One view is that the amendment serves important values. The task of courts is to accommodate those values with the individual's interest in a federal remedy for the state's violation of his rights. The governmental-proprietary distinction draws a line between situations where the state interest in immunity should prevail and those where the individual's interest in a remedy is the more compelling. The other view is that the immunity survives only because it is

brought "in law or equity" against a state "by Citizens of another State, or by Citizens or Subjects of any Foreign State." The amendment, phrased as a jurisdictional bar, makes no provision for state consent to suit. Nonetheless, "the Supreme Court, in deciding eleventh amendment cases, has focused not on the language of the eleventh amendment, but on the concept of sovereign immımity of which it is a reminder . . . " Tribe, Intergovernmental Immunities in Litigation, Taxation, and Regulation: Separation of Powers Issues in Controversies About Federalism, 89 HARv. L. REv. 682, 684 (1976). Thus, the amendment bars suits by a state's own citizens, see Hans v. Louisiana, 134 U.S. I (1890); suits by foreign governments, see Monaco v. Mississippi, 292 U.S. 313 (1934); suits nominally brought by other states, but seeking to enforce individuals' claims, see New Hampshire v. Louisiana, 108 U.S. 76 (1883); and suits in admiralty, see Ex parte New York, 256 U.S. 490 (1921). At the same time, a state may be sued if it consents, see Murray v. Wilson Distilling Co., 213 U.S. 151, 172 (1909); Clark v. Barnard, 108 U.S. 436, 447 (1883), or if it engages in conduct amounting to a waiver, see Parden v. Terminal Ry., 377 U.S. 184, 192 (1964).

${ }^{87}$ Mr. Justice Frankfurter and Mr. Justice Brennan have been its two strongest critics on the Court. See Employees of the Dep't of Pub. Health \& Welfare v. Department of Pub. Health \& Welfare, 411 U.S. 279, 309-24 (1973) (Brennan, J., dissenting); Kennecott Copper Corp. v. State Tax Comm'n, 327 U.S. 573, 580 (1946) (Frankfurter, J., dissenting).

ss See, e.g., Employees of the Dep't of Pub. Health \& Welfare v. Department of Pub. Health \& Welfare, 411 U.S. 279, 284 (1973); Bank of Ky. v. Wister, 27 U.S. (2 Pet.) 318, 332 (1829); Bank of the United States v. Planters' Bank, 22 U.S. (9 Wheat.) 904, 906 (1824). See generally Thurston, Government Proprietary Corporations, 21 VA. L. Rev. 351, 372-91 (1935). 
embedded in the Constitution, that it serves no important values, and that any available weapon may be used to undermine it. The governmental-proprietary distinction is one such weapon.

Perhaps the latter view is correct, but the possibility that the distinction is justified as a means of reconciling eleventh amendment values with other social goals should not be dismissed lightly. What follows is an effort to develop a model of eleventh amendment law in which use of the distinction can be justified, to note the objections to such a model, and to consider what standards should control the characterization of activity as governmental or proprietary if the distinction is to serve its justifiable purpose. Thereafter some attention is given to the possiblity that the distinction is merely a rhetorical device used to deny immunity.

\section{The Distinction as a Means of Accommodation}

In developing the model, it will be helpful to consider how the distinction has been utilized in eleventh amendment law. Then the purposes underlying its use will be examined. Finally, consideration will be given to the questions of what standards should be used to draw the distinction if these purposes are to be achieved, and whether some other device might better serve those aims.

a. How has the governmental-proprietary distinction been utilized in eleventh amendment law?

Some courts have used the distinction in determining whether the immunity bars suits against state agencies. ${ }^{89}$ The principal issue in these cases is whether such entities as port authorities, potato commissions, and universities ${ }^{90}$ are alter egos of the state, entitled to immunity, or are independent entities lacking the state's protection from suit. ${ }^{.1}$ Most courts resolve these cases by inquiring

se generally Note, A Practical View of the Eleventh Amendment-Lower Court Interpretations and the Supreme Court's Reaction, 61 Geo. L.J. 1473, 1484-87 (1973); Recent Developments-Constitutional Law-The Eleventh Amendment as Applied to State Agencies: A Survey of the Cases and a Proposed Model for Analysis, 22 VilL. L. REv. 153 (1976) [hereinafter cited as Recent Developments].

0 See, e.g., Roberson v. Dale, 464 F. Supp. 680 (M.D.N.C. 1979) (state university); Maryland Port Admin. v. SS Am. Legend, 453 F. Supp. 584 (D. Md. 1978); Idaho Potato Comm'n v. Washington Potato Comm'n, 410 F. Supp. 171 (D. Idaho 1975).

1 See Mt. Healthy City School Dist. Bd. of Educ. v. Doyle, 429 U.S. 274 (1977). The problem of determining whether an agency or political subdivision is the state arises in two 
whether the funds to pay a judgment would come from the state treasury or from an independent fund,,$^{92}$ or whether under state law the agency operates independently of legislative control. ${ }^{93}$ Courts often refer to the question whether the agency is performing a governmental or proprietary function as a factor in resolving the alter-ego issue, but few of them devote much attention to this question.94 Occasionally a court emphasizes an agency's governmental functions in concluding that the eleventh amendment bars

contexts. One is when the plaintiff sues on a federal cause of action and the defendant asserts the eleventh amendment as a bar. See, e.g., Sartin v. City of Columbus Util. Comm'n, 421 F. Supp. 393 (N.D. Miss. 1976), aff'd, 573 F.2d 84 (5th Cir. 1978); Idaho Potato Comm'n v. Washington Potato Comm'n, 410 F. Supp. 171 (D. Idaho 1975). The other is when the plaintiff sues on a state law cause of action, claiming diversity of citizenship. States themselves are not citizens for purposes of diversity jurisdiction. See Moor v. County of Alameda, 411 U.S. 693, 717 (1973). If a state agency, however, does not qualify as the state for purposes of the eleventh amendment, it usually qualifies as a citizen for purposes of diversity jurisdiction. See State Highway Comm'n v. Utah Constr. Co., 278 U.S. 194 (1929); S.J. Groves \& Sons v. New Jersey Turnpike Auth., 268 F. Supp. 568, 571 (D.N.J. 1967).

Diversity cases and federal question cases differ in that a state cannot consent to diversity jurisdiction, see $i d$., and state law may immunize an agency that does not constitute the state for diversity purposes. See Lenoir v. Porters Creek Watershed Dist., 586 F.2d 1081, 1089 \& n.9 (6th Cir. 1978). These differences are not significant for purposes of this article. The governmental-proprietary distinction goes to the issue of whether an entity is the state, and most courts treat this issue similarly in the federal question and diversity contexts. See Recent Developments, supra note 89, at 157 n.36 (1976). Not everyone agrees that the same standards should govern these two inquiries. See id. at 157 ("Since different consequences result from holding a state agency to be the alter ego of the state for purposes of diversity jurisdiction as opposed to the eleventh amendment, different considerations should control the issue's resolution."). One court specifically has challenged the role of the governmentalproprietary distinction in determining the alter-ego issue for diversity purposes. See Krisel v. Duran, 386 F.2d 179, 181 (2d Cir. 1967), cert. denied, 390 U.S. 1042 (1968).

${ }^{22}$ See, e.g., Ford Motor Co. v. Department of Treasury, 323 U.S. 459, 464 (1945); MillerDavis Co. v. Illinois State Toll Highway Auth., 567 F.2d 323, 326-31 (7th Cir. 1977); Doris Trading Corp. v. SS Union Enterprise, 406 F. Supp. 1093, 1095-96 (S.D.N.Y. 1976); Kardon v. Hall, 406 F. Supp. 4, 7 (D. Del. 1975); 21 Properties, Inc. v. Romney, 360 F. Supp. 1322, 1325 (N.D. Tex. 1973).

${ }^{2 s}$ See, e.g., Mt. Healthy City School Dist. Bd. of Educ. v. Doyle, 429 U.S. 274, 280 (1977); Kansas Turnpike Auth. v. Abramson, 275 F.2d 711, 713 (10th Cir.), cert. denied, 363 U.S. 813 (1960); Gordenstein v. University of Del., 381 F. Supp. 718, 722 (D. Del. 1974); Raymond Int'l Inc. v. M/T Dalzelleagle, 336 F. Supp. 679, 680 (S.D.N.Y. 1971); S.J. Groves \& Sons v. New Jersey Turnpike Auth., 268 F. Supp. 568, 579 (D.N.J. 1967).

24 See, e.g., Jackson Sawmill Co. v. United States, 580 F.2d 302, 308 (8th Cir. 1978), cert. denied, 439 U.S. 1070 (1979); Urbano v. Board of Managers, 415 F.2d 247, 251 (3d Cir. 1969), cert. denied, 397 U.S. 948 (1970); Hanshaw v. Delaware Technical \& Community College, 405 F. Supp. 292, 300 (D. Del. 1975); King v. Caesar Rodney School Dist., 396 F. Supp. 423, 426 (D. Del. 1975); Carmel v. San Juan Constr. Co., 387 F. Supp. 916, 918 (D.P.R. 1974). 
the suit. ${ }^{95}$ Other courts have indicated that the governmental nature of an agency's functions is not by itself a sufficient justification for immunity. ${ }^{96}$ Some courts emphasize the proprietary nature of an agency's activities in denying immunity defenses, ${ }^{97}$ but at least one court has stated that even agencies engaged in proprietary activities remain outside the amendment only if they satisfy the more important tests of independence..$^{88}$

The governmental-proprietary distinction has also been employed in connection with immunity claims concerning congressionally enacted causes of action. In a series of cases beginning with Parden v. Terminal Railway Co., ${ }^{\text {9日 }}$ the Supreme Court has addressed the issue of how Congress can abrogate the eleventh amendment: Does it ever make a difference from an eleventh amendment perspective that the plaintiff bases his cause of action not on common law or directly on the Constitution, but on a federal statute? If Congress has power to override the immunity by creating causes of action against the state, what are the limits of its power, and how shall it be determined whether Congress has exercised it?

For purposes of tracing the role of the governmental-proprietary distinction in answering these questions, the law on congressional authorization may be summarized as follows. ${ }^{100}$ Under its power to implement the substantive guarantees of the fourteenth amend-

os See, e.g., Wihtol v. Crow, 309 F.2d 777, 782 (8th Cir. 1962)(secondary school); Oklahoma Real Estate Comm'n v. National Business and Property Exch., 229 F.2d 205, 207 (10th Cir. 1955).

of See, e.g., Miller-Davis Co. v. Illinois State Toll Highway Auth., 567 F.2d 323, 328-30 (7th Cir. 1977); Doris Trading Corp. v. SS Union Enterprise, 406 F. Supp. 1093, 1095 (S.D.N.Y. 1976) ("If the Authority is not an 'alter ego' of the state, the fact that it is performing governmental functions has no bearing upon the question of whether it is cloaked by the Eleventh Amendment . . . ."); Raymond Int'l Inc. v. M/T Dalzelleagle, 336 F. Supp. 679, 682 (S.D.N.Y. 1971) (bridge and tunnel authority); S.J. Groves \& Sons Co. v. New Jersey Turnpike Auth., 268 F. Supp. 568, 578-79 (D.N.J. 1967).

${ }^{27}$ See, e.g., International Longshoremen's Ass'n v. North Carolina Ports Auth., 511 F.2d 1007 (4th Cir. 1975); Maryland Port Admin. v. SS Am. Legend, 453 F. Supp. 584, 590 (D. Md. 1978).

98 See Clifton v. Grisham, 381 F. Supp. 324, 326 (N.D. Miss. 1974) (wildlife commission).

9377 U.S. 184 (1964). See Fitzpatrick v. Bitzer, 427 U.S. 445 (1976); Edelman v. Jordan, 415 U.S. 651 (1974); Employees of the Dep't of Pub. Health \& Welfare v. Department of Pub. Health \& Welfare, 411 U.S. 279 (1973).

${ }^{100}$ For a detailed account of the law on congressional authorization, see Field, The Eleventh Amendment and Other Sovereign Immunity Doctrines: Congressional Imposition of Suit upon the States, 126 U. PA. L. REv. 1203 (1978). 
ment, Congress may abrogate the state's immunity for both governmental and proprietary activities. ${ }^{101}$ The scope of Congress's authority to override immunity under its article I powers is less certain. There are some "integral governmental functions" that Congress cannot regulate at all-much less regulate through authorizmg lawsuits by individuals-under its commerce power. ${ }^{102}$ It may be that Congress can authorize suit whenever it may substantively regulate. ${ }^{103}$ The eleventh amendment may bar congressional authorization of private suits, however, in some situations where Congress may substantively regulate. ${ }^{104}$ Thus, there is some authority for the proposition that Congress validly may authorize private suits only when the activity is proprietary. ${ }^{100}$ On the other hand, it might be that Congress may validly authorize private lawsuits only when the state has waived its immunity from suit. ${ }^{108}$ If

${ }^{101}$ See Fitzpatrick v. Bitzer, 427 U.S. 445, 452-56 (1976). See also Hutto v. Finney, 437 U.S. 678, 693 (1978); Field, supra note 100, at 1232 \& n.143.

${ }^{102}$ See National League of Cities v. Usery, 426 U.S. 833, 851-52, 855 (1976). On the scope of this limitation, see Field, supra note 100, at 1219-21 \& nn.86-88. This limit on the commerce power may not extend to Congress's other powers. See 426 U.S. at 852 n.17 (expressing "no view" on the question).

${ }^{103}$ See Employees of the Dep't of Pub. Health \& Welfare v. Department of Pub. Health \& Welfare, 411 U.S. 279, 300, 308-09 (1973) (focusing on the issue of congressional intent and therefore suggesting no limit on congressional power) (Brennan, J., dissenting); Parden v. Terminal Ry., 377 U.S. 184, 187-91 (1964); Jennings v. Illinois Office of Educ., 589 F.2d 935, 943 (7th Cir.), cert. denied, 441 U.S. 967 (1979); Field, supra note 100, at 1212. But see 411 U.S. at 280 ("unconsenting State is immune from suits"); Field, supra note 100, at 1214; Nowak, The Scope of Congressional Power to Create Causes of Action Against State Governments and the History of the Eleventh and Fourteenth Amendments, 75 CoLUM. L. REv. 1413, 1418 (1975).

106 The possibility should be noted, however, that the bar to congressional regulation of "integral governmental activities" will someday be deemed the same as the (as yet unsettled) bar to congressional authorization of suit in connection with governmental activities. The two situations differ in that the authorization of private lawsuits more seriously threatens the state's autonomy than does mere regulation. Thus, the range of "governmental" activities may be broader than the range of "integral governmental functions."

${ }^{105}$ See Parden v. Terminal Ry., 377 U.S. 184, 196-98 (1964). See also National League of Cities v. Usery, 426 U.S. 833,854 \& n.18 (1976) (Parden, which permitted an individual to sue a state on a federal statutory cause of action, is inapposite, apparently because it involved the operation of a railroad while this case involves integral governmental functions.); International Longshoremen's Ass'n v. North Carolina Ports Auth., 511 F.2d 1007, 1008-09 (4th Cir. 1975) (hike Parden, refusing immunity for state proprietary activity); Note, Monetary Remedies Against the State in Federal Question Cases, 68 Nw. U.L. REv. 544, 548 (1973).

${ }^{108}$ See Edelman v. Jordan, 415 U.S. 651, 671-74 (1974); Parden v. Terminal Ry., 377 U.S. 184, 192 (1964). 
so, the characterization of the activity as proprietary may bear on the waiver issue. ${ }^{107}$ Finally, given that Congress may validly authorize private suits, the issue arises whether Congress has done so in particular statutes. In Employees of the Department of Public Health and Welfare v. Department of Public Health and Welfare, ${ }^{108}$ the Supreme Court required a stronger showing of congressional intent to authorize private suits where the state activity is governmental than where it is proprietary..$^{109}$

As the tentative language of this summary suggests, the Court has not spoken with clarity on these issues. The possibihity that, apart from its power to implement the fourteenth amendment, Congress may authorize suit against the states only in connection with their proprietary activities is based on a doubtful reading of Parden, ${ }^{110}$ a fifteen-year old Supreme Court case, and on some lower court cases that have relied on that reading of Parden. ${ }^{111}$ The statement that the governmental-proprietary distinction may be relevant to waiver derives from oblique language in Edelman $v$. Jordan ${ }^{112}$ to the effect that congressional authorization is insufficient to deprive the states of their eleventh amendment immunity without a finding of waiver; ${ }^{113}$ from language in the Edelman dis-

${ }^{107}$ See Edelman v. Jordan, 415 U.S. 651, 695 (1974) (Marshall, J., dissenting); Parden v. Terminal Ry., 377 U.S. 184, 196-98 (1964); Rothstein v. Wyman, 467 F.2d 226, 238 (2d Cir. 1972), cert. denied, 411 U.S. 921; Knight v. New York, 443 F.2d 415, 418 (2d Cir. 1971). Cases like Rothstein and Knight may stand for the proposition that the governmental-proprietary distinction relates to the waiver issue because the opinions use the language of waiver to describe their holdings. The cases appear to share, however, the premise that waiver turns largely upon how the court characterizes the activity. If waiver is not to be based on a voluntariness test, as Mr. Justice Marshall suggests it should, see Edelman v. Jordan, 415 U.S. 651, 688-96 (1974) (Marshall, J., dissenting); Employees of Dep't of Pub. Health \& Welfare v. Department of Pub. Health \& Welfare, 411 U.S. 279, 295-97 (1973) (Marshall, J., concurring), but solely on the characterization of the activity as governmental or proprietary, then a waiver determination is the equivalent of a determination that congressional power can override the amendment at least whenever an activity is proprietary. See Field, supra note 100, at 1222-27 \& n.122.

108411 U.S. 279 (1973).

${ }^{100}$ See id. at 282-85.

110 See Nowak, supra note 103, at 1417 (Parden "provides little guidance," as it is "subject to at least three different interpretations," none of which limits congressional power strictly to proprietary activities.).

111 See, e.g., International Longshoremen's Ass'n v. North Carolina Ports Auth., 511 F.2d 1007, 1008-09 (4th Cir. 1975).

112415 U.S. 615 (1974).

113 After finding that Congress had not authorized suit, see id. at 672, the Court discussed whether the state had waived its immunity, see id. at 673-74. Some of its waiver language 
sent suggesting that the court should find waiver when the activity is proprietary; ${ }^{114}$ and from parts of the Parden opinion that seem to rely on the proprietary nature of the regulated activity as a basis for finding that the state had waived its immunity. ${ }^{118}$ The conclusion that the governmental-proprietary distinction may be useful in alter-ego cases is called into question by the statement in Edelman that the relevant criterion in determining if a suit is against the state is whether the state pays the recovery. ${ }^{116}$ Indeed no recent Supreme Court case on the eleventh amendment forthrightly employs the governmental-proprietary distinction for any purpose other than determining congressional intent, and one author has concluded that the distinction plays no role at all in determining the scope of congressional power. ${ }^{117}$

The ensuing discussion nevertheless proceeds on the premise that until the Supreme Court rules to the contrary, the scattered case references to the distinction must be taken seriously. It also

implies that "waiver" is synonymous with congressional authorization. See, e.g., id. at 673 (provision in Social Security Act "did not authorize suit by anyone and, standing alone, fell far short of a waiver by a participating state of its Eleventh Amendment immunity"). Some of the opinion suggests that action on the part of the state is necessary to a finding of waiver. See, e.g., id. at 673 ("The mere fact that a state participates in a program through which the federal government provides assistance for the operation by the state of a system of public aid is not sufficient to establish consent on the part of the state to sue and be sued in the federal courts."). See also Field, supra note 100, at 1212-13 (characterizing the Court's position on congressional authorization as "difficult to decipher"); Tribe, supra note 86, at 688 (describing the Court's approach to the congressional authorization and waiver problems as "schizophrenic").

216 415 U.S. at 695-96 (Marshall, J., dissenting) (citing Employees of Dep't of Pub. Health \& Welfare v. Department of Pub. Health \& Welfare, 411 U.S. 279 (1973), to argue that the courts can find waiver more easily in proprietary activities).

115377 U.S. at 196-98.

118 See 415 U.S. at 667-69. Relying on Edelman, some lower courts have suggested that the source of funds to pay a judgment is the sole criterion in alter-ego cases. See, e.g., Kardon v. Hall, 406 F. Supp. 4, 7 (D. Del. 1975); Clifton v. Grisham, 381 F. Supp. 324, 326 (N.D. Miss. 1974). Cf. Jackson Sawmill Co. v. United States, 580 F.2d 302, 308-09 (8th Cir. 1978) (citing not Edelman but the case Edelman relied on, Ford Motor Co. v. Indiana Dep't of Treasury, 323 U.S. 459, 464 (1945)), cert. denied, 99 S. Ct. 839 (1979). Reliance on Edelman for this point seems unwarranted. The Court there addressed not the alter-ego question but the extent to which monetary rehief may be granted in a case where jurisdiction depends on Ex parte Young, 209 U.S. 123 (1908) (injunctive rehef not barred by eleventh amendment). See 415 U.S. at 667. In Mt. Healthy City School Dist. Bd. of Educ. v. Doyle, 429 U.S. 274, 279-80 (1977), the Court stressed the independence of a local board of education, and not the source of funds to pay the judgment, in denying an alter-ego claim. See generally Moor v. County of Alameda, 411 U.S. 693, 717-18 (1973) (discussing the alter-ego problem).

${ }^{117}$ See D. CuRRIE, supra note 8, at 565. 
assumes that the distinction serves the purpose of accommodating the state and individual interests described below, so that efforts to elucidate its content and to evaluate its utility in light of this purpose may clarify its place in eleventh amendment law. We reserve for the next section an examination of the distinction on the alterative assumption that it is merely a device employed to limit immunity.

\section{b. What purpose is served by the governmental-proprietary distinction?}

Defenders of the eleventh amendment have put forward two state interests to justify the immunity. ${ }^{118}$ Some have argued that the eleventh amendment safeguards the states' financial position against the threat of large damage awards. ${ }^{119}$ Others emphasize the

${ }^{118} \mathrm{Mr}$. Justice Holmes held the view that "[a] sovereign is exempt from suit . . . on the logical and practical ground that there can be no legal right as against the authority that makes the law on which the right depends." Kawananakoa v. Polyblank, 205 U.S. 349, 353 (1907). Kawananakoa was not an eleventh amendment case, but it has been cited in eleventh amendment cases for its explanation of immunity. See Employees of Dep't of Puh. Health \& Welfare v. Department of Pub. Health \& Welfare, 411 U.S. 279, 288 (1973) (Marshall, J., concurring). This means of justifying the immunity is objectionable on several grounds. First, it appears to rest on Austin's notion that law is the command of the sovereign, see C. Jacobs, The Eleventh AMEndment ANd Sovereign Immunity 155 (1972), a concept of law that Hart has criticized effectively, see, e.g., H.L.A. HART, THE CONCEPT OF LAW 77 (1961) ("[T] he simple model of law as the sovereign's coercive orders fail[s] to reproduce some of the salient features of a legal system."). See generally id. at 18-76. Second, the framers no more wrote Austin's jurisprudence into the Constitution than they did Herbert Spencer's economics. Third, diversity cases based on state law do not constitute the most significant group of eleventh amendment cases. Even if there were no eleventh amendment, such cases could not be brought in federal court unless the state permitted suit in state court. See Lenoir v. Porters Creek Watershed Dist., 586 F.2d 1081, 1089 (6th Cir. 1978). Rather, the more important class of eleventh amendment cases involve causes of action arising from federal constitutional or statutory law, and Mr. Justice Holmes's objection does not apply to them.

119 See, e.g., Employees of Dep't of Pub. Health \& Welfare v. Department of Pub. Health \& Welfare, 411 U.S. 279, 284-85 (1973) (The Court will not hightly presume that Congress intended to place "enormous fiscal burdens" on the state.); Cohens v. Virginia, 19 U.S. (6 Wheat.) 264, 406-07 (1821) (eleventh amendment motivated by a desire to leave to a state "the full power of consulting its convenience in the adjustment of its debts"). See also Parden v. Terminal Ry, 377 U.S. 184, 187 (1964) ("[S]uit on state debt obligations without the State's consent was precisely the evil against which . . . the Eleventh Amendment . . . [was] directed . . . ."); Ford Motor Co. v. Department of Treasury, 323 U.S. 459, 464 (1945) (suit is against state, and therefore barred by eleventh amendment, if judgment would be levied against state treasury); Ex parte Young, 209 U.S. 123 (1908) (injunctive relief not prohibited by the amendment); Nowak, supra note 103, at 1421 (characterizing Edelman as 
values of federalism and the threat to those values posed by the supremacy of federal law and the federal courts over state governments; in the face of federal power, state immunity from suit in federal court safeguards state autonomy and sovereignty. ${ }^{120}$ These two purposes are not inconsistent. A state's autonomy from the federal government depends significantly on its financial independence, and discussions of the amendment's purposes often touch on both the financial and the autonomy rationales. ${ }^{121}$ Separating them, however, facilitates analysis, because justification of a governmental-proprietary distinction becomes more difficult if the eleventh amendment protects state finances rather than state autonomy as such.

A lawsuit arising out of activities characterized as proprietary threatens a state's finances to the same extent as one arising out of

ruling that " $[t]$ he basic purpose of the amendment . . . was to prevent disruption of state treasuries by retroactive relief"); id. at 1428-29, 1436, 1444; Tribe, supra note 86, at 687 ("[T]he operational concept of a sovereign immunity that is secure against judicial inroads has been retained in at least tbe core area of damage suits.").

${ }_{120}$ See, e.g., Fitzpatrick v. Bitzer, 427 U.S. 445,456 (1976) (referring to "the principle of state sovereignty which it [the eleventh amendment] embodies"); Edelman v. Jordan, 415 U.S. 651,660 (1974) (citing the state's fear of federal judicial power to summon a state as a defendant). The Court in Edelman quoted Alexander Hamilton's pronouncement: " 'It is inherent in the nature of sovereignty not to be amenable to the suit of an individual without its consent. . . . and the exemption, as one of the attributes of sovereignty, is now enjoyed by the government of every State in the Union." " 415 U.S. at 660 n.9 (quoting THE FEDERALIST No. 81, as quoted in Monaco v. Mississippi, 292 U.S. 313, 324 (1934)) (emphasis in original). These statements referred to the original Constitution, but can be relied on to show the purpose of the eleventh amendment on the premise that the amendment corrected the Supreme Court's "error" in Chisholm v. Georgia, 2 U.S. (2 Dall.) 419 (1793), and restored the intent of the framers. See Great Northern Life Ins. Co. v. Read, 322 U.S. 47, 51 (1944) (States have immunity because of "[t]he inherent nature of sovereignty."); In re Ayers, 123 U.S. 443, 505 (1887) (purpose of immunity is to prevent the indignity of subjecting states to coercive process); Bank of the United States v. Planters' Bank, 22 U.S. (9 Wheat.) 904, 907 (1824) (By becoming a shareholder in a bank the state "divests itself . . of its sovereign character."); D. CuRRIE, supra note 8, at 559-61. Cf. Georgia v. City of Chattanooga, 264 U.S. 472, 481 (1924) (refusing to enjoin city's condemnation proceedings against property owned by foreign state) (Georgia's "enterprise in Tennessee is a private undertaking .... [A]s to that property, it cannot claim sovereign privilege or immunity."). See also Tribe, supra note 86, at 697 (The Court should not lightly infer congressional inroads on state autonomy.).

121 See, e.g., Jennings v. Illinois Office of Educ., 589 F.2d 935, 943 (7th Cir.) (In the circumstances, "[n]either of the reasons commonly advanced for the reluctance to hold states liable for damages-the burden on their treasuries and the intrusion into their processes-apphies . . . ."), cert. denied, 441 U.S. 967 (1979); C. JACOBS, supra note 118, at 153-54 (rejecting both fiscal protection and sovereign autonomy as justification for the amendment). 
activities characterized as governmental. If protection of the state's finances is one discrete goal of the eleventh amendment, it makes sense to accommodate the eleventh amendment immunity with the individual's interest in a federal court remedy by permitting injunction suits but not suits for damages. ${ }^{122}$ It may also make sense to distinguish between suits seeking a recovery from the state treasury and those seeking a recovery from a state agency that is supported by a separate state fund. ${ }^{123}$ The governmental-proprietary distinction, however, does not help distinguish between situations where the state has a strong financial interest and those where its interest is weak.

If the state interest in protecting its sovereign autonomy against the power of the federal courts is the more siguificant rationale for the eleventh amendment, the governmental-proprietary distinction rests on a firmer foundation. Here the nature of the state activity in question can make a difference in terms of the asserted state interest. The state's immunity claim would be stronger for activities that more closely relate to its status as an independent sovereign than in connection with other activities. A court could accommodate the state's interest in immunity and the individual's interest in suing in federal court by denying immunity for those state activities it deemed less important to the state's sovereign autonomy, and it could label this class of activities "proprietary."124

An analysis of the possible roles a governmental-proprietary distinction could play in accommodating state and individual interests must also consider the possibility that the individual's interest in a remedy is stronger in some contexts than in others. If so, the governmental-proprietary distinction might, depending on the criteria used to draw it, separate out those state activities where the individual has that strong interest and label them proprietary.

133 See Ex parte Young, 209 U.S. 123 (1908). But see Edelman v. Jordan, 415 U.S. 651, 667 (1974) (noting that injunctions often have impact on state treasury).

${ }^{123}$ See, e.g., Miller-Davis Co. v. Illinois State Toll Highway Auth., 567 F.2d 323, 327 (7th Cir. 1977); Kardon v. Hall, 406 F. Supp. 4, 7-8 (D. Del. 1975); Bowen v. Hackett, 387 F. Supp. 1212, 1221-22 (D.R.I. 1975); Gordenstein v. University of Del., 381 F. Supp. 718, 722 (D. Del. 1974).

134 Thus it would he appropriate for a court that emphasized the defense of the state's autonomy as the goal of the immunity to draw a governmental-proprietary distinction. See Georgia v. City of Chattanooga, 264 U.S. 472 (1924); Bank of Ky. v. Wister, 27 U.S. (2 Pet.) 318 (1829); Bank of the United States v. Planters' Bank, 22 U.S. (9 Wheat.) 904, 906 (1824). 
Scattered indications in the cases show that some courts have used the governmental-proprietary distinction to isolate those strong individual interests. ${ }^{125}$ The argument, never fully articulated, seems to be that the individual whom the government wrongs while acting as governments ordinarily do should recognize that permitting his suit could harm the public interest. Lawsuits could inhibit the government in carrying out functions that serve the public welfare, including the welfare of the person who wishes to sue. An individual who deals with the government acting in ways similar to those of private business, however, cannot reasonably be expected to perceive a difference between the government and business. Accordingly, the plaintiff has a stronger fairness argument for a federal remedy in the latter circumstances than in the former.

Two points should be noted in connection with this argument. First, it rests on the premise that fairness to individuals depends not just on how strong the state's interest is, but also on how strong the individual perceives it to be. Second, if this fairness rationale is viable, then the individual's interest in a remedy furnishes some basis for a governmental-proprietary distinction even under the financial theory of the amendment, as the fairness rationale does not depend on distinguishing among activities on the basis of the state's interest in immunity.

${ }^{125}$ See Parden v. Terminal Ry., 377 U.S. 184, 197 (1964) ("It would surprise our citizens, we think, to learn that petitioners, who in terms of the language and purposes of the FELA are on precisely the same footing as other railroad workers, must be denied the benefit of the Act simply because the railroad for which they work happens to be owned and operated by a State rather than a private corportion."); Green v. Utah, 539 F.2d 1266, 1274 (10th Cir. 1976) (Subordination of hardship caused by the immunity "[p]articularly . . . seems acceptable where a governmental function is involved."). Cf. City of Trenton v. New Jersey, 262 U.S. 182, 192 (1923) (explaining that in common-law sovereign immunity, the governmentalproprietary distinction is "applied to escape difficulties, in order that injustice may not result from the recognition of technical defenses based upon the governmental character of such corporations"). As one commentator observes:

The occasions for harmful official activity that give rise to civil liability are perhaps most numerous when officials act in proprietary capacities. Being run over by a postal truck looks like a common, garden-variety tort . . . . The analogy to private functions ... is so close that failure to hold the government or its officials liable seems strange [but is not uncommon].

Mashaw, Civil Liability of Government Officers: Property Rights and Official Accountability, 42 LaW \& CoNTEMP. ProB. 8, 13-14 (1978). 


\section{c. How can the accommodation of interests best be achieved?}

This question can be divided into two separate inquiries. First, is the governmental-proprietary distinction the best way to achieve the purpose of accommodating state and individual interests or is some other device more effective in achieving that goal? Second, given that the governmental-proprietary distinction will be used to make the accommodation, what criteria should be used to separate governmental from proprietary functions? The answer to the first question depends in part on the answer to the second. If courts cannot develop clear and useful standards for making the governmental-proprietary distinction, some other means of accommodating interests likely will be more effective.

The courts have devoted little attention to articulating the criteria used to distinguish governmental from proprietary activities. Courts often assert, witlout analysis, that a particular activity is governmental or proprietary. ${ }^{128}$ Courts that offer reasons for their decisions lave developed two ways of distinguishing governmental from proprietary activities. Some courts describe governmental activity with words like "essential" and "necessary"127 or point out that the state's constitution or a statute mandates the activity. ${ }^{128}$ Courts that make sucl arguments appear to be using the importance of the state activity as their standard. Their test might be called the essential-government-function test.

Other courts empliasize not the importance of the governmental activity but whether the government customarily performs it. They

${ }^{128}$ See, e.g., Bagrowski v. American Export Isbrandtsen Lines, Inc., 440 F.2d 502, 509 (7th Cir. 1971) (employer-stevedore) (proprietary); Wihtol v. Crow, 309 F.2d 777, 782 (8th Cir. 1962) (secondary school) (governmental); Kansas Turnpike Autb. v. Abramson, 275 F.2d 711, 713 (10th Cir.) (proprietary), cert. denied, 363 U.S. 813 (1960); United States v. Fuston, 143 F.2d 76, 78 (10th Cir.) (administration of public lands) (governmental), cert. denied, 323 U.S. 768 (1944); Sartin v. City of Columbus Util. Comm'n, 421 F. Supp. 393, 400 (N.D. Miss. 1976) (proprietary), aff'd, 573 F.2d 84 (5th Cir. 1978); Pullman Inc. v. Volpe, 337 F. Supp. 432, 441 (E.D. Pa. 1971) (transportation authority) (proprietary).

${ }^{127}$ See, e.g., Oklahoma Real Estate Comm'n v. National Business and Property Exch., 229 F.2d 205, 207 (10th Cir. 1955) ("necessary"); Fowler v. California Toll-Bridge Auth., 128 F.2d 549, 550 (9th Cir. 1942) ("necessary"); DeLong Corp. v. Oregon State Highway Comm'n, 233 F. Supp. 7, 15 (D. Or. 1964) ("essential"), aff'd, 343 F.2d 911 (9th Cir.), cert. denied, 382 U.S. 877 (1965); Florida State Turnpike Auth. v. Van Kirk, 146 F. Supp. 364, 365 (S.D. Fla. 1956) ("essential").

118 See, e.g., Sehlmeyer v. Romeo Co., 117 F.2d 996, 998 (9th Cir. 1941) (statutory duty to dredge harbor); Roberson v. Dale, 464 F. Supp. 680, 689 (M.D.N.C. 1979) (education mandated by state constitution). 
describe governmental activities as those "traditionally" or "historically" performed by government, and proprietary ones as those that are "business" or "commercial" or performed for profit, all descriptions of traditionally private activities. ${ }^{128}$ While this traditional-government-function standard better draws the governmental-proprietary distinction than does the essential government function test, the latter standard has one notable argument in its favor.

An essential-function test provides a more flexible means of determining whether a given activity is crucial to the state's sovereign independence than does the traditional-function test. Changes in the demands made on governments can make some government activities essential today or tomorrow, even though they were not functions of government in the past. At one time, for example, education was a function of the private sector; today education is one of the primary duties of government. A test that emphasizes the traditional pursuit of an activity by the state probably will prove less flexible in responding to government's changing role than an essential-function test. Even if courts deem new state activities traditional when they have characteristics in common with more customary state functions, such a test will be less responsive than the essential-function test to changes in the public's perception of the state's proper role. Those who do not value the immunity highly and wish to restrict its scope might view this as an advantage of the traditional-function test. Putting aside judgments as to the immunity's value, however, the comparative ridigity of the traditional-function test diminishes its usefulness as a means of identifying state activities that deserve immunity.

${ }^{120}$ See, e.g., Employees of the Dep't of Pub. Health \& Welfare v. Department of Pub. Health \& Welfare, 411 U.S. 279, 284 (1973) (Parden, in which Alabama operated a railroad " "for profit," " concerned an "area where private persons and corporations normally ran the enterprise."); Green v. Utah, 539 F.2d 1266, 1272-74 (10th Cir. 1976) (regulation of securities is historically one of a state's governmental powers); International Longshoremen's Ass'n v. North Carolina Ports Auth., 511 F.2d 1007, 1008 (4th Cir. 1975) (when state operates a port authority it "leaves its traditional governmental activity and enters a proprietary enterprise"); Maryland Port Admin. v. SS Am. Legend, 453 F. Supp. 584, 590 (D. Md. 1978) (state agency "waives the protection of sovereign immunity and the Eleventh Amendment when it . . . engages in business of a proprietary or commercial nature"); McKethan v. Virginia, 370 F. Supp. 1, 4 (E.D. Va.) (distinguishing activities carried on "for profit" from those "traditionally governmental" and holding bank regulatory commission to be governmental), aff'd, 508 F.2d 838 (4th Cir. 1974), cert. denied, 422 U.S. 1045 (1975). 
If flexibility is an advantage of the essential-function test, its greatest disadvantage is its vagueness. In practice it may be hard to distinguish between essential and nonessential activities. Courts resort to intuitive judgments in determining what constitutes an essential government function, holding, for example, that a turnpike authority, a highway commission, a toll bridge authority, and a public lands agency all involve essential government functions. ${ }^{130}$ A review of the cases has located not a single one denying that any state activity is an essential government function. ${ }^{131}$ Even if they tried, courts may be unable to develop more explicit criteria for determining what state functions are essential. It would be difficult to explain, for instance, why a state-operated railroad that promotes commerce and thereby contributes to the state's economic welfare is less essential than a turnpike commission, whose ultimate aim is much the same as that of the railroad; or why either is less essential than a state police force, one major purpose of which is to protect trade and commerce.

The traditional-state-function test furnishes a clearer guideline for separating governmental from proprietary functions. The benchmark is the kind of activity historically engaged in by governments. Thus, the case of the state-operated railroad is easily decided against immunity. However important railroads may be to a state's economy, states have not traditionally operated them. New activities that have some features similar to traditionally private activity and some features similar to traditionally public activity would present more difficult line-drawing problems. Examples might include the turnpike authority or a state-owned farm that produces food and then distributes it to needy residents. The law, however, commonly faces such problems, and this standard remams more concrete than the essential-government-function test.

The traditional-state-function test has other advantages as well

130 See cases cited in note 127 supro.

131 Perhaps Idaho Potato Comm'n v. Washington Potato Comm'n, 410 F. Supp. 171, 17476 (D. Idaho 1975), is an exception to this generalization. There the court used the language "essential governmental function" to describe the test. It then shifted its focus, however, and concluded that the function of both potato commissions was "to carry out advertising and promotion which traditionally is not a governmental function." Id. This change of emphasis merely underscores the practical advantage of the traditional-function test as an effective way of distinguishing among state activities. Whether the economic welfare of a state depends on the promotion of potatoes is a more involved inquiry than whether the state traditionally has engaged in the activity. 
over the essential-function standard. First, it requires a less intrusive inquiry into the state's affairs. The federal court asks only whether the states commonly have engaged in a particular activity. The essential-function test requires the federal court to examine the goals served by the program, to evaluate the importance of those goals, and to determine how effectively the program achieved those goals. In view of the amendment's purpose to limit intrusions by federal courts into the state's affairs, it seems appropriate to prefer the less intrusive traditional-function standard. Second, if courts have more difficulty determining which state activities are essential than which are traditional, it must also be harder for individuals. The argument that it is more equitable to exempt the state from legal responsibihty when it engages in governmental activity depends in part on the different perceptions individuals have as to the relationship of the activity to the general welfare. If they are unable to tell which activities are proprietary and which are governmental, as may often be the case under an essential-government-function test, they will not perceive that it is more just to hold the state immune in some cases than in others. Thus, the continuing viability of the distinction's fairness rationale calls for application of the traditional-state-function test and not the vague essential-government-function test.

Although tradition is a better test than importance, there remain the questions of how the tradition test serves the purpose of accommodating state and individual interests, and whether some other device might be inore effective. The cases do not provide much guidance on how the traditional-state-function test accomplishes the accommodation function. Perhaps courts assume that the state interest in sovereign autonomy is strongest in activities that states traditionally pursue. States likely consider such activities to be within their domain, and the states' customary pursuit of these activities may also indicate their importance. Federal interference with them is especially repugnant to the states' independence. At the same time, individuals may perceive that lawsuits regarding traditional state activities may threaten the general welfare more than suits concerning other state functions. Thus, the governmental-proprietary distinction, using a traditional-governmental-function test to draw the distinction, recognizes both the strong state interest in immunity where the activity involves a traditional state function and the strong individual interest in a 
remedy where the state engages in a traditionally private activity. ${ }^{132}$

The remaining question is whether some other device might better achieve the accommodation of state and individual interests. Mr. Justice Marshall's dissenting opinion in Edelman v. Jordan ${ }^{133}$ suggests one approach, although it is unclear whether he considered it an alternative to the governmental-proprietary distinction. ${ }^{134}$ Justice Marshall first posited that Congress cannot authorize suit in federal court against the state under its article I powers in the absence of a waiver of immunity by the state. ${ }^{135} \mathrm{He}$ then proposed that in making the waiver determination a court should consider whether there has been "voluntary action by the State . . which could reasonably be construed as evidencing its consent to suit in a federal forum." "138 Edelman was a suit brought to recover for Illinois's alleged violation of federal regulations governing a federal-state program of Aid to the Aged, Blind, and Disabled. The regulations applied only to states that chose to accept federal funds. On these facts Mr. Justice Marshall concluded the state voluntarily had submitted to federal regulation and waived its immunity from suit. He noted that "the Social Security Act does not impose federal standards and liability upon ... often-unwilling state agencies. . . . [but] seeks to induce state participation in the federal welfare programs by offering federal matching funds in exchange for the State's voluntary assumption of the Act's requirements." 137 By taking part in the program under these conditions, the state "voluntarily subordinated its sovereignty in this matter to that of the Federal Government."138

Although Justice Marshall did not address the issue, a rationale for his voluntariness test may be stated in terms of accommodating interests. In his view, the state has less interest in defending its

13s A similar explanation could be provided with the essential-government-function test as the criterion for drawing the distinction. The analysis would emphasize that the state's essential functions are more closely connected to its sovereign autonomy than are other state activities, and that individuals are more likely to perceive the threat to the general welfare of suits challenging essential activities.

123415 U.S. 651 (1974).

1st See id. at 688-90, 695-96 (1974) (Marshall, J., dissenting).

135 See id. at 688-89.

136 Id. at 695 .

137 Id. at 688 .

138 Id. at 695 . 
sovereign autonomy when it voluntarily participates in a federal program than when it is an unwilling object of regulations, regardless of whether the program is governmental or proprietary. ${ }^{139} \mathrm{Mr}$. Justice Marshall's approach has intuitive appeal. A state concerned about its sovereign autonomy could maintain its independence by steering clear of involvement with the federal government. When a state accepts money from the federal government, the federal government appropriately may require the state to give up some of its independence and accept the federal government's rules regarding expenditure of the money even where the activity in question is traditionally governmental.

Mr. Justice Marshall's Edelman dissent, however, does not elucidate this voluntariness test sufficiently to permit a confident evaluation of its merits in comparison with the governmental-proprietary distinction. In particular, it is unclear what standards would govern the determination of whether a state voluntarily has submitted to federal regulation. Would the state's receipt of money through participation in a federal program always justify the conclusion that the state voluntarily had acquiesced in the accompanying federal regulation? If so, the federal government might find ways to evade the immunity in almost any context by making the states offers they could not refuse. Arguably, for example, the states do not participate voluntarily in the Aid to the Aged, Blind, and Disabled program. Few state officers mindful of pohtical realities could reject such offers of federal money. ${ }^{140}$ If, however, the state were permitted to refute an inference of voluntariness by pointing to the surrounding circumstances, the voluntariness test might prove as vague as the essential-function test.

A further question is how the voluntariness test would apply to state activities other than participation in federal programs, where the federal government is a regulator of an "unwilling" state. One possibility would be to deny that a state could ever be deemed to have submitted voluntarily to suit unless it enters a federal program knowing that it must comply with federal rules. This, however, does not appear to be Mr. Justice Marshall's solution. In-

1s9 Id.

140 See generally Kaden, Politics, Money, and State Sovereignty: The Judicial Role, 79 Colum. L. REv. 847, 874-83 (1979) (discussing federal grants to the states that impose a variety of restrictions upon the states). 
stead, he falls back on the governmental-proprietary distinction to make such determinations, for he states that proprietary activity may "more easily" be found voluntary than governmental. ${ }^{141}$ It does seem a plausible inference that a state could usually extricate itself from activities commonly performed by business more easily than from traditionally governmental activities, if only because the private sector would often replace the government in the former situation. The opinion gives no hint, however, of what, if any, criteria besides the governmental-proprietary distinction the courts could use to resolve the voluntariness issue in such cases, and some understanding of these criteria is necessary to an evaluation of the voluntariness test. To the extent that the governmental-proprietary distinction determines voluntariness, Mr. Justice Marshall's voluntariness test is more a supplement to the distinction than an alternative.

\section{Other Perspectives on the Governmental-Proprietary Dis- tinction}

The model outhned above offers an orderly body of functionally related principles, whereas the Court's opinions generally lack any coherent discussion of principle or function. In the model, the purposes of the eleventh amendment are to protect state finances and to defend the state's sovereign autonomy. Some cases support these purposes, but more often the cases ignore any consideration of the amendment's goals. Moreover, some elements of eleventh amendment law are inconsistent with one or the other of these purposes. ${ }^{142}$ In the model, the governmental-proprietary distinction functions to accommodate state and individual interests, but again the cases do not explicitly discuss accommodation.

The model suggests that the distinction serves this function adequately only if in the hierarchy of eleventh amendment purposes preservation of state sovereign autonomy has precedence over protection of the state fisc, or if the strength of the individual interest

\footnotetext{
161415 U.S. at 695-96 (Marshall, J., dissenting).

142 For example, federal courts may enjoin state officers in cases where they may not award damages against the state, see Edelman v. Jordan, 415 U.S. 651 (1974); Ex parte Young, 209 U.S. 123 (1908), a rule that does not square with the sovereign-autonomy rationale. The rule that a state may consent to suit in its own courts while remaining immune in federal courts, see Smith v. Reeves, 178 U.S. 436, 445 (1900), seems somewhat at odds with a financial rationale for the amendment.
} 
in a remedy is stronger in a proprietary than a governmental context. The model requires that the Court explicitly consider what standards for making the governmental-proprietary distinction would best accommodate interests; it suggests that some cases have correctly used the traditional-state-function criterion as the standard; and it recognizes that, before adhering to the governmental-proprietary distinction as a means for making the accommodation, the Court should consider other alternatives, specifically Mr. Justice Marshall's voluntariness test. The Court has paid no attention to any of these matters.

The lack of coherence in eleventh amendment law extends beyond issues directly related to the governmental-proprietary distinction. The Court has failed to set forth clear answers to questions such as whether Congress may authorize suit in the absence of a waiver by the state and what state conduct amounts to a waiver. Parts of Parden read as though Congress may authorize suit whenever it acts within its delegated powers. ${ }^{143}$ Other parts suggest that a state must waive its immunity. ${ }^{144}$ Employees can be read as permitting Congress to impose suit on the states under any of its powers, ${ }^{145}$ but that conclusion remains uncertain because the narrow holding of the case was that Congress had not acted explicitly enough to warrant a judgment by the Court that it intended to permit private suits. Edelman undercut an expansive reading of Employees by once again introducing, in dicta, the notion that even when Congress has authorized suit, the court must find a waiver by the state. ${ }^{146}$ Then in Fitzpatrick $v$. Bitzer ${ }^{147}$ the Court ruled that, acting under its power to enforce the substantive guarantees of the fourteenth amendment, Congress could abrogate the immunity without restriction. It left unclear the scope of this exception to the eleventh amendment, and this ambiguity permitted a lower court to rely on the decision in ruling that Congress could

${ }^{143}$ See 377 U.S. at 189-91. The opinion's author interprets it this way. See Employees of the Dep't of Pub. Health \& Welfare v. Department of Pub. Health \& Welfare, 411 U.S. 279, 300-01 (1973) (Brennan, J., dissenting) (admitting that the holding in Parden was "perhaps not unambiguously phrased").

144 See, e.g., 377 U.S. at 192.

${ }^{148}$ See 411 U.S. at 283-84; id. at 308-09 (Brennan, J., dissenting); Jennings v. Illinois Office of Educ., 589 F.2d 935, 940 (7th Cir.), cert. denied, 441 U.S. 967 (1979); Mills Music Co. v. Arizona, 591 F.2d 1278, 1283 (9th Cir. 1979).

146415 U.S. at $671-77$.

s47 427 U.S. $445,454-55$ (1976). 
similarly override immunity when acting pursuant to its article I war powers. ${ }^{148}$

The chaotic state of eleventh amendment law suggests another explanation of the use of the governmental-proprietary distinction that does not attempt to reconcile cases or find a niche for the distinction in an orderly body of principles. The alternative explanation is that the governmental-proprietary distinction is nothing more than a persuasive rhetorical device, borrowed from the familiar common law of sovereign immunity, that a judge may use to convince himself or his brothers that the court can reconcile a denial of immunity with constitutional text and history. So long as the court does not articulate the purposes served by the distinction and the criteria used to make it, the court may safely ignore the question whether it is justifiable to invoke the distinction to deny immunity. Accordingly, the cryptic opinions and the lack of elaboration of these points may indicate that the distinction cannot be justified in terms of the purposes served by the amendment and their accommodation with other values.

Before condemning the courts for such deceptive practices, however, another explanation for the incoherence of contemporary eleventh amendment law must be considered. Although the amendment dates from 1798, the Supreme Court paid comparatively hittle attention to it, and no attention at all to the problem of congressional authorization of suit, before the 1964 case of Parden v. Terminal Railway Co. ${ }^{149}$ Perhaps the Court is still feeling its way toward answering the inquiries made here into the purpose of the amendment, the functions of the distinction, and the appropriate standards for making the distinction. ${ }^{150}$ If so, the gov-

14s See Peel v. Florida Dep't of Transp., 600 F.2d 1070, 1080-81 (5th Cir. 1979). See also Jennings v. Illinois Office of Educ., 589 F.2d 935, 941-43 (7th Cir.), cert. denied, 441 U.S. 967 (1979).

148 377 U.S. 184 (1964).

${ }^{180}$ Mr. Justice Frankfurter wrote with regard to the federal government's immunity from suit: "In varying degrees, at different times, the momentum of the historic doctrine is arrested or deflected by an unexpressed feeling that governmental immunity runs counter to prevailing notions of reason and justice. Legal concepts are then found available to give effect to this feeling . . . ." Larson v. Domestic \& Foreign Commerce Corp., 337 U.S. 682, 709 (1949) (dissenting). Perhaps the Parden opinion, with its suggestion of a governmentalproprietary distinction, was just the beginning of an effort to give expression to the widespread contemporary feeling that governments should not always be free from suit. See also Employees of the Dep't of Pub. Health \& Welfare v. Department of Pub. Health \& Welfare, 411 U.S. 279, 311-12 (1973) (Brennan, J., dissenting) (characterizing Parden as an example 
ernmental-proprietary distinction may face one of three fates. If the Court can erect an analytical foundation similar to or better than the one offered here, the distinction will survive and flourish. If the Court cannot build such a foundation-if, for example, the Court should deem the financial purpose for the immunity to be a strong one--then the distinction may be abandoned. The third alternative is that the Court will remain divided as to the proper scope of the eleventh amendment and the governmental-proprietary distinction will continue to appear in opinions written by judges who accept the principle of accommodation that is articulated here or who develop some other basis for it, as well as opinions written by judges who dislike the immunity and wish to limit it in whatever way possible. In the absence of some consensus on the Court as to the amendment's purposes and limits, the governmental-proprietary distinction will remain a vague and uncertain aspect of eleventh amendment law. The legitimacy of its role will remain unsettled so long as the Court cannot speak with a clear voice on these larger eleventh amendment issues.

\section{Relationships Among Immunity Doctrines}

Before concluding the examination of state immunity doctrines, it will be worthwhile to consider briefly the relationships among the different immunity doctrines in hight of the courts' tendency to view the governmental-proprietary distinction as a single dichotomy regardless of context. The governmental-proprietary distinction is employed in connection with common-law sovereign immunity of states, common-law municipal tort habihty, and the sovereign immunity of foreign nations. Courts have sometimes drawn upon the distinction as used in common-law sovereign immunity in deciding tax immunity cases ${ }^{151}$ and eleventh amendment cases. ${ }^{152}$ The Supreme Court has invoked both tax immunity and eleventh amendment cases in holding states and cities immune from some forms of federal regulation. ${ }^{153}$ Members of the Court have relied on tax immunity and eleventh amendment cases in fashioning a governmental-proprietary distinction in foreign sover-

of Justice Frankfurter's hypothesis).

${ }^{161}$ See, e.g., South Carolina v. United States, 199 U.S. 437, 461-63 (1905).

${ }_{162}$ See cases cited in note 20 supra.

${ }^{163}$ See National League of Cities v. Usery, 426 U.S. 833, 843 (1976). 
eign immunity, ${ }^{154}$ and in determining the application of the antitrust laws to cities and states. ${ }^{185}$

The apparent premise underlying these opinions is that the governmental-proprietary distinction is controlled by the same standards and holds the same content in each of these contexts. That premise is wrong. The accommodating function that the distinction may serve in the eleventh amendment context, for example, demands that the courts draw the distinction between essential or traditional state activities, on the one hand, and less important or traditionally commercial activities on the other. Common-law sovereign immunity and municipal tort immunity do not share the eleventh amendment's concern for state autonomy, nor do they threaten the individual's assertion of federal constitutional or statutory rights in a federal forum. Accordingly, they do not require accommodation of those competing considerations, and the courts will not fashion the standards used to separate governmental from proprietary activities with the aim of achieving such an accommodation. The standards will instead serve whatever purposes the courts believe underle the distinction in these branches of the law.. ${ }^{158}$

Suppose, for example, the distinction in common-law sovereign immunity recognizes that government officials need immunity to make important policy decisions without the inhibitory effect of potential lawsuits in the event of some mishap, but that this goal is

\footnotetext{
${ }^{1 s 4}$ See Alfred Dunhill, Inc. v. Republic of Cuba, 425 U.S. 682, 695-96 (1976) (plurality opinion).

${ }^{135}$ City of Lafayette v. Louisiana Power \& Light Co., 435 U.S. 389, 422-24 (1978) (Burger, C.J., concurring). Cf. Note, supra note 12 , at 596-97 \& n.130 (Because courts use the governmental-proprietary distinction in municipal law, they should also use it in antitrust law.).

${ }^{158}$ Considerable confusion surrounds this point in the municipal tort area. The distinction may have been thought a necessary consequence of the "assumed dual character of the city as an autonomous corporation and as an agent of the state." Borchard, Government Liability in Tort, 34 Yale L.J. 129, 131 (1924). See generally Frug, The City as a Legal Concept, 93 Harv. L. Rzv. 1057 (1980). Perhaps the motivation for the distinction was to place a limit on the scope of the duty of care owed by a municipality, which might otherwise be boundless. Cf. W. Prosser, supra note 9, § 131, at 986 (4th ed. 1971) (finding it 'unthinkable that . . . a municipality should be held liable for a wrong decision of its courts"). The Supreme Court has suggested that the distinction is an "awkward and contradictory" means of escaping what would otherwise be an absolute immunity. Indian Towing Co. v. United States, 350 U.S. 61, 65 (1955). See also City of Trenton v. New Jersey, 262 U.S. 182, 191-92 (1923). Professor Davis notes, however, that courts first found municipalities liable for all their torts and concludes that the distinction is an unprincipled means of creating immunity where none existed in its absence. See $3 \mathrm{~K}$. DAvis, supra note 6 , § 25.07, at 459 \& n.2.
} 
not served by immunizing city activities that resemble private business activities. ${ }^{167}$ Factors hike the level of generality of a decision and the extent to which the threat of lawsuit might inhibit effective decisionmaking in particular contexts should control the distinction drawn for this purpose. ${ }^{158}$ Thus, a state's construction of highways may be a sufficiently traditional governmental activity to qualify for eleventh amendment immunity, ${ }^{159}$ while the day-to-day operation of a highway department may be insufficiently policy oriented to qualify for common-law immunity. ${ }^{160}$

Similarly, foreign sovereign immunity for acts of state apparently serves to avoid embarrassment to the executive branch in its conduct of foreign affairs. ${ }^{161} \mathrm{~A}$ governmental-proprietary distinction may be a useful device for separating situations where such embarrassment is hikely from those where it is not. If so, the courts should fashion the standards used to make it with the problem of embarrassment in mind; the standards may bear little resemblance to the eleventh amendment standards that seek to accommodate state and individual interests. In each of these contexts the content given the distinction should suit the purpose for which it is drawn. Cases decided in one context, under criteria appropriate to that context, are not useful in determining the distinction's content in areas where it serves different purposes.

Some recent Supreme Court opinions have used cases from other contexts, not as a means of determining how the distinction should be applied in a different area, but to establish that the Court has developed a governmental-proprietary distinction and should now employ it in this new context. ${ }^{162}$ This use of cases from other contexts is no more defensible than using them to determine whether

${ }^{157}$ See Elgin v. District of Columbia, 337 F.2d 152, 154-55 (D.C. Cir. 1964). The D.C. Circuit later decided that a "discretionary-ministerial" distinction best achieved this aim. See Spencer v. General Hosp., 425 F.2d 479 (D.C. Cir. 1969).

158 See 337 F.2d at 154-55.

${ }_{159}$ See, e.g., Fowler v. California Toll-Bridge Auth., 128 F.2d 549, 550 (9th Cir. 1942); DeLong Corp. v. Oregon State Highway Comm'n, 233 F. Supp. 7, 15-17 (D. Or. 1964), aff'd, 343 F.2d 911 (9th Cir.), cert. denied, 382 U.S. 877 (1965).

${ }_{180}$ See W. Prosser, supra note 9, § 131, at 982 \& n.19. But see Sweigard v. Pennsylvania Dep't of Transp., $454 \mathrm{~Pa}$. 32, 34-35, 309 A.2d 374, 376 (1973).

${ }_{161}$ See Alfred Dinnhill, Inc. v. Republic of Cuba, 425 U.S. 682, 697 (1976) (plurality opinion); Heaney v. Government of Spain, 445 F.2d 501, 503 (2d Cir. 1971).

${ }_{182}$ See City of Lafayette v. Louisiana Power \& Light Co., 435 U.S. 389, 422-24 (1978) (Burger, C.J., concurring); Alfred Dunhill, Inc. v. Republic of Cuba, 425 U.S. 682, 696-98 (1976) (plurality opinion). 
a given activity is governmental or proprietary. The distinction's merit in a particular context depends on whether it effectively serves some purpose there. That it effectively serves a purpose in one area does not mean that it will effectively serve some other purpose in another area. This point seems straightforward enough, but it appears to have escaped the Supreme Court's attention. Indeed, the recent citations of tax immunity cases, where the Court itself abandoned the distinction, as authority for using the distinction in foreign sovereign immunity and in antitrust law, suggests that members of the Court beheve that the discredited invocation of the distinction in one context supports its use in other contexts. It appears that the Court has given insufficient thought to the differences among the various governmental-proprietary distinctions.

\section{The Governmental-Proprietary Distinction as a Means} for Distinguishing Between the Government as a Regulator of the Market and as a Participant in the Market

When the focus of the inquiry shifts from the use of the governmental-proprietary distinction as a mechanism for limiting a constitutional immunity and turns to its use as a mechanism for relaxing a constitutional constramt, one confronts a governmentalproprietary distinction that shares in fundamental respects little more than a label with the distinction discussed in Part II. Indeed, in a broad sense, the distinction plays an opposite role: in the immunity context, despite differences in the purposes served by the distinction depending on the particular immunity at issue, the impact of characterizing an activity as proprietary is always to saddle the state with some burden that it otherwise would not have to bear; in the context about to be explored, the impact of characterizing an activity as proprietary is generally to liberate the state from a burden it otherwise would have to bear. Some commentators have found the different implications of the distinction perplexing. Professor Tribe, for example, feels that "it would be odd if the Court meant to treat the proprietary character of state action ... as cutting in favor of the state [in the negative commerce clause context] while regarding the proprietary character of state activities generally as cutting against state immunity from federal 
regulation in National League of Cities." ${ }^{163}$ Yet such inconsistent treatment is not at all odd. It simply reflects the different purposes underlying the governmental-proprietary distinction in different contexts.

\section{A. Constitutional Protection of Individual Rights}

When governments act as procurers or providers of goods and services, they sometimes invoke a governmental-proprietary distinction to support their contention that they are not subject to the same constitutional restrictions protecting individual rights as when they act as regulators of the general public. For example, the state of Florida successfully defended a statute requiring it to buy printing services from in-state suppliers, over a potential out-ofstate supplier's equal protection challenge, by arguing that the purchase of printing services was a proprietary and not a governmental activity. ${ }^{164}$ Using similar arguments, the city of Shaker Heights successfully defended its rejection of political advertising on city buses over first amendment objections, ${ }^{168}$ and the Civil Service Commission withstood a due process attack on its refusal to allow some charitable groups to solicit employees at work while permitting others to do so. ${ }^{166}$ In other cases, the courts have permitted governments to conduct searches of their employees that would otherwise violate the fourth amendment ${ }^{167}$ and to place limits on the political activities of their employees that would viclate the first amendment if imposed on the public at large. ${ }^{168}$

Other courts have rejected arguments that the proprietary nature of a government's activities shields it from constitutional attack. Thus, New York City was barred on first amendment grounds from forbidding unpopular speech in a restaurant located

16s Tribe, supra note 7, at 1072 n.34 (citation omitted) (emphasis in original). See also L. TriBE, supra note 82, at 337.

${ }^{284}$ American Yearbook Co. v. Askew, 339 F. Supp. 719 (M.D. Fla.), aff'd mem., 409 U.S. 904 (1972).

${ }^{16 s}$ Lehman v. City of Shaker Heights, 418 U.S. 298, 303-04 (1974) (plurality opinion).

${ }^{286}$ United Black Fund, Inc. v. Hampton, 352 F. Supp. 898, 905-06 (D.D.C. 1972).

${ }^{267}$ See, e.g., United States v. Coles, 302 F. Supp. 99 (D. Me. 1969). See also Gardner v. Broderick, 392 U.S. 273, 278 (1968) (dicta indicating that government could fire an employee who insisted on exercising his right against self-incrimination); Comment, Government Employee Searches and the Fourth Amendment, 1970 WASH. U.L.Q. 86.

${ }^{18 s}$ United States Civil Serv. Comm'n v. National Ass'n of Letter Carriers, 413 U.S. 548, 556 (1973); Broadrick v. Oklahoma, 413 U.S. 601, 616 (1973). 
on its property. ${ }^{169}$ Cleveland was not permitted under the first amendment to ban the sale of Penthouse magazine at a newsstand in a municipally owned airport. ${ }^{170}$ Rutgers University was rebuffed on equal protection grounds when it tried to refuse transcripts and deny the right to re-register to a former student whose prior student loan had been discharged in bankruptcy. ${ }^{171}$

These cases raise several issues. One set of questions concerns the differences in result among the cases: Is the first group reconcilable with the second, and, if not, which cases are correct? If the two groups can be reconciled, how can this be accomplished? What is the principle underlying them all? Another set of questions concerns the relation of these cases to the immunity cases discussed in the previous section: Are the criteria for distinguishing between governmental and proprietary activities the same in the two contexts? If not, what is the justification for the difference?

The first set of questions has received considerable attention from the courts. Courts have refused to invoke mechanically a governmental-proprietary distinction as the basis for denying a constitutional claim. ${ }^{172}$ At the same time, the courts have recognized that the government's interest as a procurer or provider of goods and services differs from its interest in regulating the conduct of members of the public and that this difference sometimes adequately justifies a rule that the court would strike down if applied to the public at large. Thus, many of the seemingly conflicting cases can be reconciled on their facts. In some cases the government has a sufficiently strong proprietary interest to prevail; in others, it does not. As for the second set of questions, although some opinions suggest that the distinction is the same in the individual constitutional rights context as in the immunity context, ${ }^{173}$ in fact a wholly different rationale underhes the distinction when invoked in the

\footnotetext{
16s Anderson v. Moses, 185 F. Supp. 727 (S.D.N.Y. 1960).

${ }^{170}$ Penthouse Int'l, Ltd. v. Putka, 436 F. Supp. 1220 (N.D. Ohio 1977).

171 Handsome v. Rutgers Univ., 445 F. Supp. 1362 (D.N.J. 1978).

172 See, e.g., Penthouse Int'l, Ltd. v. Putka, 436 F. Supp. 1220, 1226-27 (N.D. Ohio 1977) (upholding first amendment claim brought under 42 U.S.C. $\$ 1983$ (1976) despite proprietary nature of airport). There are exceptions. See, e.g., Sherman v. City of Pasadena, 367 F. Supp. 1115, 1117 (C.D. Cal. 1973) ("The court holds tbat $\$ 1983$ does not apply to officials of a non-federal governmental unit when they act in a proprietary and not in a governmental capacity, and hence does not afford a basis of relief for plaintiff's claim of misapplication of Pasadena's personnel procedures.").

${ }^{173}$ See, e.g., Sherman v. City of Pasadena, 367 F. Supp. 1115, 1117-18 (C.D. Cal 1973).
} 
constitutional rights cases, and the content of the labels "governmental" and "proprietary" should thus differ from their content in immunity law. In the individual constitutional rights context, governmental activity is regulation of the general public, while proprietary activity includes any of the government's dealings with individuals in the procurement or provision of goods and services, for example, as employer, buyer, seller, or landlord.

The reasoning behind these conclusions begins with a consideration of the purpose for which courts draw a distinction between different kinds of government activities in cases where an individual claims that the state has violated his constitutional rights. That purpose is to recognize the significant differences between the interests the government might reasonably assert in support of rules governing the public at large and the interests it might assert to justify rules for dealing with employees, tenants, and the like. As a regulator of the general public, the government must base its proscription of an activity on the premise that the proscription will act to enhance the general welfare. The government may attempt to justify a restriction on free speech, for example, on the ground that speech supporting the overthrow of the government harms the general welfare, ${ }^{174}$ that the teaching of foreign languages in private schools discourages assimilation of immigrants into American life, ${ }^{175}$ or that the public distribution of handbills litters the streets. ${ }^{176}$ As a procurer or provider of goods and services, however, it may assert a different, more specific kind of interest-the interest of an employer who needs an efficient workforce, a landlord who would prefer not to deal witl tenants who do not pay rent, or a purchaser who wishes to contract with a trustworthy seller. This quasi-business interest may adequately support regulation that a court might strike down if it applied to the public at large and the state supported it with arguments that it promotes the general welfare.

Pickering $v$. Board of Education ${ }^{177}$ is an illustrative case. There

174 See, e.g., Gitlow v. New York, 268 U.S. 652, 667-70 (1925) (statute upheld).

178 See, e.g., Meyer v. Nebraska, 262 U.S. 390, 397-98, 403 (1923) (justification rejected and statute prohibiting the teaching of foreign language to students below the eighth grade level overturned).

178 See, e.g., Schneider v. State, 308 U.S. 147, 156, 162 (1939) (justification rejected and statute overturned).

${ }^{127} 391$ U.S. 563 (1968). 
the Court invalidated on first amendment grounds the dismissal of a public school teacher for writing a nonlibelous letter to a newspaper criticizing the Board's administration of the schools. After noting that the state may not freely subject its employees to "unreasonable" conditions, ${ }^{178}$ the Court stated the applicable principles as follows:

[I]t cannot be gainsaid that the State has interests as an employer in regulating the speech of its employees that differ significantly from those it possesses in connection with regulation of the speech of the citizenry in general. The problem in any case is to arrive at a balance between the interests of the teacher, as a citizen, in commenting upon matters of public concern and the interest of the State, as an employer, in promoting the efficiency of the public services it performs through its employees. ${ }^{179}$

On the facts of Pickering, the teacher's "employment relationships with the Board and ... the superintendent [were] not the kind of close working relationships for which it can persuasively be claimed that personal loyalty and confidence are necessary to their proper functioning." "The Board also failed to show that the teacher's statements "in any way either impeded the teacher's proper performance of his daily duties in the classroom or . . . interfered with the regular operation of the schools generally." The Court concluded that, in the circumstances of the case, the Board's interest in restricting the teacher's speech was "not significantly greater than its interest in limiting a similar contribution [to pubhic debate] by any member of the general public."182 Just as a member of the general public could not be held to account for writing a nonlibelous letter, neither could Mr. Pickering.

The case makes several points. First, public employees do not receive the same constitutional protection in their dealings with the government as an employer as do individuals who confront the

178 See id. at 568.

17" Id. The Court acknowledged that "[i]t is possible to conceive of some positions in public employment in whicb the need for confidentiality is so great that even completely correct public statements might furnish a permissible ground for dismissal." Id. at 570 n.3. See also Mailloux v. Kiley, 323 F. Supp. 1387 (D. Mass.), aff'd per curiam, 448 F.2d 1242 (1st Cir. 1971).

${ }^{180} 391$ U.S. at 570.

131 Id. at $572-73$ (citation omitted).

sas Id. at 573 . 
government as a regulator of private conduct. Second, the difference arises from the government's significantly different interest as an employer than as a regulator of conduct generally. Third, the presence of this different interest does not signal a victory for the government. In the circumstances of the particular case, the government's interest may not be strong enough to overcome the individual's claim to constitutional protection. ${ }^{183}$

${ }_{183}$ These points are elaborated in Van Alstyne, The Constitutional Rights of Public Employees: A Comment on the Inappropriate Use of an Old Analogy, 16 U.C.L.A. L. REv. 751 (1969). In particular, see id. at 769-71.

The problem presented in Pickering and other cases where the government asserts a business-like interest is one aspect of the broader question of the constitutional restraints on the government's treatment of individuals with whom it contracts or to whom it distributes largesse in the administration of public enterprises. See generally Monaghan, Of "Liberty" and "Property", 62 CoRnell L. Rev. 405 (1977); Reich, The New Property, 73 Yale L.J. 733 (1964); Van Alstyne, Cracks in "The New Property": Adjudicative Due Process in the Administrative State, 62 Cornell L. REv. 445 (1977); Van Alstyne, The Demise of the Right-Privilege Distinction in Constitutional Law, 81 HARv. L. Rev. 1439 (1968). This section seeks only to show that courts use the term "proprietary" in these cases as a means of denoting a government's business-like interest and to compare that use of the term with its use in other constitutional contexts.

Not every opinion can be reconciled with the standards set forth in Pickering. Consider the plurality opinion in Lehman v. City of Shaker Heights, 418 U.S. 298 (1974). A divided Court upheld against a first amendment challenge the city's policy of barring political advertisements on city buses while permitting commercial ads. Mr. Justice Blackmun's plurality opinion adverted to the proprietary nature of the activity and concluded as follows:

No First Amendment forum is here to be found. The city consciously has limited access to its transit system advertising space in order to minimize the chances of abuse, the appearance of favoritism, and the risk of imposing upon a captive audience. These are reasonable legislative objectives advanced by the city in a proprietary capacity. In these circumstances, there is no First or Fourteenth Amendment violation.

Id. at 304.

This language may be read as suggesting that when the government acts as a proprietor, it can withstand constitutional challenges merely by showing that its practices are rational. See Fora Americana, supra note 8, at 276-77. Just a year after Lehman, however, the Court, in another opinion by Justice Blackmun, implicitly rejected the proposition that the proprietary nature of government activity warranted a lower standard of first amendment review. See Southeastern Prods., Ltd. v. Conrad, 420 U.S. 546 (1975) (discussed in notes 189-90 infra and accompanying text); Restrictions of Speech, supra note 8, at 91. Furthermore, Lehman itself indicates that the plurality did not intend that proprietary activity be subject to a lower standard of review but only that the court must take into account proprietary interests. Thus, Justice Blackmun noted that

[r]evenue earned from long-term commercial advertising could be jeopardized by a requirement that short-term candidacy or issue-oriented advertisements be displayed on car cards. Users would be subjected to the blare of political propoganda [sic]. There could be lurking doubts about favoritism, and sticky administrative problems might arise in parceling out limited space to eager politicians. In these circumstances, 
Several additional conclusions may be drawn from the analysis in Pickering and the other cases in this area. First, no basis exists for restricting this analytical framework to employee cases. The government's position as a procurer or provider of goods and services will generally indicate a narrower and stronger government interest than the interest in the general welfare that supports public regulation. The government's interest in buying from trustworthy suppliers might support a statute barring public contracts with convicted felons, ${ }^{184}$ even if an attempt to prevent private businesses from entering similar contracts would fail. The government's interest as a landlord in ridding itself of uncooperative tenants may justify its eviction of a tenant on the same terms as a private landlord, without a hearing and without even giving reasons. ${ }^{185}$

These cases suggest a second conclusion: The courts should use the term "proprietary" only to describe the peculiar, business-like interest the government can rely upon to rebut a constitutional claim asserted by an individual with whom it does or rejects business. The term does not help in cases where the constitutional challenge concerns a government that, while engaged in business dealings, cannot assert a business justification for its actions. For example, in Chicago Housing Authority v. Stewart, ${ }^{186}$ the court allowed the government acting as a landlord to evict a tenant under the terms of its lease, without affording him a hearing or giving

the managerial decision to limit car card space to innocuous and less controversial commercial and service oriented advertising does not rise to the dignity of a First Amendment violation.

418 U.S. at 304.

184 See Polyvend, Inc. v. Puckorius, 77 Ill. 2d 287, 395 N.E.2d 1376 (1979) (upholding statute barring convicted felons from public contracts on the ground that the opportunity to contract for the sale of goods and services to the government does not amount to a legally protected property interest to which due process guarantees attach).

${ }^{18 s}$ See United States v. Blumenthal, 315 F.2d 351, 353 (3d Cir. 1963); Chicago Hous. Auth. v. Stewart, 40 Ill. 2d 23, 25, 237 N.E.2d 463, 464 (1968) ("The Housing Authority is acting in a proprietary capacity rather than a governmental one, and has the same right as any other landlord to terminate a monthly lease by giving appropriate notice and to recover possession of its property without being required to give reasons for the action."), vacated and remanded on other grounds, 393 U.S. 482 (1969). But see Escalera v. New York City Hous. Auth., 425 F.2d 853, 861 (2d Cir.) ("The government cannot deprive a private citizen of his continued tenancy, without affording him adequate procedural safeguards . . .."), cert. denied, 400 U.S. 853 (1970).

${ }_{188} 40$ Ill. 2d 23, 237 N.E.2d 463 (1968), vacated and remanded on other grounds, 393 U.S. 482 (1969). 
any reasons for its actions. The facts suggested that the tenant was unreliable about paying rent. Suppose, however, the tenant could show that the state actually evicted him for his expression of unpopular opinions. The Illinois Supreme Court pointed out that it would require a different result in such a case. ${ }^{187}$ Eviction for such a reason would not serve the government's business interests. The Constitution presumably would not prevent a private landlord from evicting a tenant because of what he says or writes, even if blind prejudice motivates him. The government, however, may assert only legitimate proprietary interests, such as efficiency or the assurance of trustworthy business associates. It does not enjoy the full panoply of rights belonging to proprietors. ${ }^{188}$

Cases like the hypothetical suggested above will not often arise. More frequently, the government will assert some legitimate interest in support of its actions. Even so, when the interest asserted does not relate to business considerations, the term "proprietary" will not be helpful in describing it. In Southeastern Promotions, $L t d$. $v$. Conrad, ${ }^{189}$ for example, the city of Chattanooga refused to permit a production of Hair at a municipally owned auditorium. The city objected to the play's content but had no business concern that the auditorium would lose money if the play were performed. The Court implicitly rejected the governmental-proprietary distinction in holding the city's action improper in the absence of sufficient procedural safeguards for first amendment rights. For present purposes, the important point is not that the state lost, but that the Court correctly eschewed the governmentalproprietary distinction as an aid in the analysis. The government's interest in safeguarding the public morals against sexually-oriented plays is not a business interest and the term "proprietary" does not help describe such an interest. That term is useful only when the state can argue that business considerations permit it broad discretion in dealing with employees and other business con-

187 Id. at 26,237 N.E.2d at 465.

188 See Penthouse Int'l, Ltd. v. Putka, 436 F. Supp. 1220, 1229 (N.D. Ohio 1977) (Cleveland, which asserted no business justification for its action, could not bar Penthouse magazine from a municipal airport newsstand by contract with franchisee in the absence of a prior determination of obscenity, even though the franchisee could refuse to sell it if he wished.).

189420 U.S. 546 (1975). 
tacts. ${ }^{190}$

The third conclusion drawn from these cases is that the governmental-proprietary distinction they employ is a wholly different construct from the distinction drawn in the immunity context. The supervision of Civil Service employees and teachers, the acquisition of license plates for the state, the operation of a state university, and the like all appear to be "traditional governmental functions," as the courts use that term in the immunity context, yet they are proprietary for purposes of adjudicating claims of constitutional violations. The differences between these two contexts provide a striking illustration of the lack of fixed content in the terms "governmental" and "proprietary." This lack of content permits courts to use the labels in a variety of contexts to describe distinctions drawn for different purposes. Accordingly, a distinction drawn to accommodate state interests in immunity with individual interests in suing the state, or with a federal interest in taxing it, should not be governed by the same criteria as a distinction drawn for the purpose of reflecting the greater interests the state has in regulating its contractual dealings with citizens than in regulating their conduct generally.

\section{B. The Negative Implications of the Commerce Clause}

1. The Use of the Governmental-Proprietary Distinction in Negative Commerce Clause Cases

The commerce clause is not only an affirmative grant of power to Congress " $[t]$ o regulate Commerce ... among the several States"; ${ }^{191}$ it is also an imphed restraint upon state legislation af-

100 Accordingly, the rejection of the distinction in Conrad may be reconciled with the result if not the reasoning of the plurality opinion in Lehman v. City of Shaker Heights, 418 U.S. 298, 303-04 (1974) (discussed at note 183 supra). In Lehman the plurality found that legitimate proprietary interests justified avoiding the customer-relations problems brought on by permitting political advertising. These proprietary interests may justify the ban on political advertising upheld by the Court. Confronting a similar question, the court in Dallas Ass'n of Community Organizations for Reform Now v. Dallas County Hosp. Dist., 478 F. Supp. 1250 (N.D. Tex. 1979), held that a public hospital is not a public forum, because the purpose and primary activity of the hospital is rendering quality health care. Quality health care requires there be no impediment to the speed with which it is given and no disturbing influences on the patients. There is a "basic incompatibility" between leafleting in the public areas of a hospital and the rendition of health care. Id. at 1257.

${ }^{191}$ U.S. CoNsT. art. I, § 8, cl. 3. 
fecting interstate commerce. In the context of these negative implications, the governmental-proprietary distinction has informed constitutional analysis largely in a single line of cases involving challenges to state purchasing or contracting requirements favoring in-state over out-of-state interests. ${ }^{102}$ It has also surfaced sporadically in cases involving commerce clause challenges to state employment ${ }^{193}$ and selling ${ }^{194}$ preferences for state residents. When invoking the distinction in connection with claims arising under the negative implications of the commerce clause, courts have attributed to the terms governmental and proprietary a meaning similar to that given to them in adjudication of individual constitutional rights. Governmental activity signifies regulation of the general citizenry; proprietary activity signifies the government's dealings as a buyer or seller of goods or services. The small body of case law under the commerce clause consistently holds that a state's action in its proprietary capacity gives rise to no constitutional objection. ${ }^{195}$

Most of the cases present variations on a common pattern. A state statute requires that all public purchasing of specified goods or services be made of goods and services produced in the state or from sellers with business operations in the state. A potential suppher of the goods or services, excluded from consideration by the state because of its inability to satisfy the statutory requirements, challenges the constitutionality of the statute under, among other

182 See, e.g., American Yearbook Co. v. Askew, 339 F. Supp. 719 (M.D. Fla.), aff'd mem., 409 U.S. 904 (1972); City of Phoenix v. Superior Court, 109 Ariz. 533, 514 P.2d 454 (1973); City of Denver v. Bossie, 83 Colo. 329, 266 P. 214 (1928); In re Gemmill, 20 Idaho 732, 119 P. 298 (1911); Collins v. Senatobia Blank Book \& Stationery Co., 115 Miss. 254, 76 So. 258 (1917); Allen v. Labsap, 188 Mo. 692, 87 S.W. 926 (1905); Hersey v. Neilson, 47 Mont. 132, 131 P. 30 (1913); Garden State Dairies, Inc. v. Sills, 46 N.J. 349, 217 A.2d 126 (1966); Treat v. Coler, 166 N.Y. 144, 59 N.E. 776 (1901); Tribune Printing \& Binding Co. v. Barnes, 7 N.D. 591, 75 N.W. 904 (1898). Cf. Hughes v. Alexandria Scrap Corp., 426 U.S. 794 (1976) (state subsidies favoring in-state businesses); MacMillan Co. v. Johnson, 269 F. 28, 31 (E.D. Mich. 1920) (price regulation of public school textbook suppliers); K.S.B. Technical Sales Corp. v. North Jersey Dist. Water Supply Comm'n, 75 N.J. 272, 381 A.2d 774 (1977) (state "Buy American" act), appeal dismissed, 435 U.S. 982 (1978); American Inst. for Imported Steel, Inc. v. County of Erie, 58 Misc. 2d 1059, 297 N.Y.S.2d 602 (Sup. Ct. 1968) (state "Buy American" act), modified, 32 A.D.2d 231, 302 N.Y.S.2d 61 (1969).

193 See, e.g., Holland v. Bleigh Constr. Co., 61 Ill. 2d 258, 335 N.E.2d 469 (1975).

${ }^{194}$ See, e.g., Reeves, Inc. v. Stake, $100 \mathrm{~S}$. Ct. 2271 (1980), discussed in the postscript at notes 252-63 infra and accompanying text.

${ }^{195}$ See notes 192-94 supra. But see notes 201-04 infra and accompanying text. 
provisions, the commerce clause. The court rejects the challenge, exphicitly or imphicitly relying on the proposition that the negative strictures of the commerce clause do not restrain the state when it acts in its proprietary capacity as a purchaser of goods or services.

Courts explain their reliance on the governmental-proprietary distinction in a number of ways. Perhaps the most frequent explanation is that when a state is carrying on its own business rather than regulating somebody else's, "we are unable to see why the state is forbidden to do what an individual certainly may do with impunity, viz. elect from whom it will purchase supplies needed in the discharge of its corporate functions." ${ }^{196}$ Courts also emphasize the narrow reach of the legislative restrictions involved; these restrictions are not directed to the public at large, but only to "the officers and agents of the state as to their duties in the discharge of certain of the business and proprietary interests of the ... people acting in their corporate capacity."197 Another recurring theme is that the state, in prescribing the conditions under which it will transact business for its own account, does not substantially affect interstate commerce. ${ }^{198}$ Although the Supreme Court has never explicitly invoked the goverumental-proprietary distinction in connection with the negative imphications of the commerce clause, it has declared that "the entry by the State itself into the market as a purchaser, in effect, of a potential article of interstate commerce"189 is not "the kind of action with which the Commerce Clause is concerned."200 By so declaring, the Supreme Court has endorsed reasoning employed by lower courts that have invoked the governmental-proprietary distinction in this context.

It appears that only two cases have failed to respect the governmental-proprietary distinction in this context. One court expressly refused to limit its scrutiny of state action under the commerce clause to the state's governmental activities "in the hight of the expanding proprietary activities of the states"; ${ }^{201}$ but that court has

100 Tribune Printing \& Binding Co. v. Barnes, 7 N.D. 591, 597, 75 N.W. 904,906 (1898).

107 In re Gemmill, 20 Idaho 732, 741, 119 P. 298, 301 (1911) (emphasis omitted).

19: See, e.g., American Yearbook Co. v. Askew, 339 F. Supp. 719, 724 (M.D. Fla.), aff'd mem., 409 U.S. 904 (1972).

190 Hughes v. Alexandria Scrap Corp., 426 U.S. 794, 808 (1976).

200 Id. at 805.

${ }^{201}$ Garden State Dairies, Inc. v. Sills, 46 N.J. 349, 358, 217 A.2d 126, 130 (1966) (holding that the proprietary nature of the state's activities would not save the statute in question if 
since reconsidered its position. ${ }^{202}$ The other case $^{203}$ has not been followed. ${ }^{204}$ In short, a thin but persistent line of authority finds in the governmental-proprietary distinction a basis for determining whether state action offends-or, in some cases, is even reviewable under-the implied restraints of the commerce clause.

\section{The Functions Served by the Governmental-Proprietary Dis- tinction in Negative Commerce Clause Cases}

To determine what functions the governmental-proprietary distinction serves in cases involving the negative implications of the commerce clause, one must first identify the purposes underlying the commerce clause itself. Only then can it be determined whether and how the distinction serves these purposes. The original purpose of the commerce clause, as the Court has frequently pointed out, was to avoid "the tendencies toward economic Bal-

plaintiff could show an undue burden on interstate commerce).

${ }^{202}$ See K.S.B. Technical Sales Corp. v. North Jersey Dist. Water Supply Comm'n, 75 N.J. 272, 299, 381 A.2d 774, 787 (1977), appeal dismissed, 435 U.S. 982 (1978). In K.S.B., the court sustained New Jersey's "Buy American" statute, which required the use of materials produced in the United States for the performance of government contracts. The challenged application involved a construction contract for a state water treatment plant. In rejecting the claim that the statute was in conflict witb the provision of the General Agreement on Tariffs and Trade (GATT) forbidding discrimination against foreign products, Protocol Modifying the General Agreement on Tariffs and Trade, Sept. 14, 1948, art. III, para. 4, 62 Stat. 3680 , T.I.A.S. No. 1890,62 U.N.T.S. 80 , the court found that the purchase fell within GATT's exception for "the procurement by governmental agencies of products purchased for governmental purposes and not with a view to commercial resale," id., para. 8(a). See 75 N.J. at 288-89, $381 \mathrm{~A} .2 \mathrm{~d}$ at 782 . The court refused to adopt a governmental-proprietary distinction in construing the GATT provisions, and quoted one of its opinions that criticized the distinction and characterized it as "illusory." 75 N.J. at 287-88, 381 A.2d at 782 (quoting Township of Washington v. Village of Ridgewood, 26 N.J. 578, 584, 141 A.2d 308, 311 (1958)). At the same time, however, the court beld that the Buy American sclieme was invulnerable to attack under the negative imphications of the commerce clause, on the ground that the state was acting as a purchaser rather than a regulator. See 75 N.J. at 293-302, 381 A.2d at 784-89. While the court apparently believed that it had avoided the governmentalproprietary distinction that it had just branded as "illusory," see id. at $297 \mathrm{n} .11,381 \mathrm{A.2d}$ at 787 n.11, the court nevertheless endorsed the reasoning of a decision that had adopted the distinction, see id. at 296-99, 381 A.2d at 786-87 (citing American Yearbook Co. v. Askew, 339 F. Supp. 719 (M.D. Fla.), aff'd mem., 409 U.S. 904 (1972)), repudiated the reasoning of its own earlier decision that had refused to adopt it, see 75 N.J. at 299,381 A.2d at 787, and implicitly made the same distinction that has been rationalized under the governmentalproprietary rubric.

${ }^{203}$ Treat v. Coler, 166 N.Y. 144, 59 N.E. 766 (1901).

204 See Allen v. Labsap, 188 Mo. 692, 699-700, 87 S.W. 926, 928 (1905); Hersey v. Neilson, 47 Mont. 132, 147-48, 131 P. 30, 34 (1913). 
kanization that had plagued relations among the Colonies and later among the States under the Articles of Confederation."'20s The grant to Congress of power to regulate commerce among the states was the centerpiece of the constitutional scheme. Even when Congress did not exercise this power, the Court, faithful to the purpose of the grant, interpreted the clause so as to provide a safeguard against economic Balkanization resulting from state legislation. The hundreds of decisions the Court has written delineating the scope of permissible state regulation in the face of congressional silence are testimony to its efforts to implement the clause's purpose to curb the "centrifugal . . . forces of localism"208 while respecting the states' legitimate policies.

The question here is whether the governmental-proprietary distinction has an analytically defensible role in the judicial search for the "dehicate balance" between the competing demands of state and national interests under the negative implications of the commerce clause. If the answer depends entirely on whether the difference between a state's governmental and proprietary activities reflects a corresponding difference between the tendencies of two kinds of government action to cause economic Balkanization, the distinction would seem to have no legitimate place in negative commerce clause analysis. For if economic Balkanization is the evil that the commerce clause was designed to prevent, what difference does it make whether the evil is brought about by states acting in their governmental or proprietary capacities? It is "established doctrine," after all, "that a state may not, in any form or under any guise, directly burden the prosecution of interstate business."207 To allow the state to Balkanize the national economy through its proprietary activities would be a triumph of form over substance-it would permit the states to do indirectly what they could not do directly and would fly in the face of the Court's express admonition. The inquiry in every case must be whether the practical effect of state action burdens the national economy and whether, under the familiar criteria the Court has fashioned for

${ }^{205}$ Hughes v. Oklahoma, 441 U.S. 322, 325 (1979).

${ }^{106}$ Brown, The Open Economy: Justice Frankfurter and the Position of the Judiciary, 67 YALE L.J. 219, 220 (1957).

${ }^{207}$ Baldwin v. G.A.F. Seelig, Inc., 294 U.S. 511, 522 (1935) (quoting International Texthook Co. v. Pigg, 217 U.S. 91, 112 (1910)). 
balancing state and national interests, the burden outweighs the benefit:

Where the statute regulates evenhandedly to effectuate a legitimate local public interest, and its effects on interstate commerce are only incidental, it will be upheld unless the burden imposed on such commerce is clearly excessive in relation to the putative local benefits. If a legitimate local purpose is found, then the question becomes one of degree. And the extent of the burden that will be tolerated will of course depend on the nature of the local interest involved, and on whether it could be promoted as well with a lesser impact on interstate activities. ${ }^{208}$

It can thus be argued that the analytical framework created by these decisional principles brooks no recourse to artificial concepts like the governmental-proprietary distinction. When a state purchases, sells, or hires in a way that favors its own residents or businesses, the national market is being Balkanized to the extent that resources are being allocated on the basis of pohtical rather than economic considerations. It is not, of course, the economically inefficient ${ }^{209}$ character of the state's action that gives rise to a commerce clause objection; economic efficiency, however desirable, is not a criterion of constitutionality under the commerce clause. ${ }^{210}$ The problem is rather that in-state preferences in state purchasing, selling, or hiring appear to violate the first substantive principle of commerce clause doctrine-that the states may not Balkanize the national economy by discriminating against interstate commerce. Any statute imposing upon the private sector a duty so to discriminate would plainly be struck down under the commerce clause in short order. And, it is asserted, when the state itself acts in such a manner, the values protected by the commerce clause are likewise offended.

${ }_{208}$ Pike v. Bruce Church, Inc., 397 U.S. 137, 142 (1970) (citation omitted).

${ }^{209}$ See Note, Home-state Preferences in Public Contracting: A Study in Economic Balkanization, 58 Iowa L. REv. 576, 591-95 (1973); Comment, In-state Preferences in Public Contracting: States' Rights Versus Economic Sectionalism, 49 U. CoLo. L. REv. 205, 209-16 (1978).

210 The states have long been able to enact legislation that, while economically inefficient, does not impinge on other values protected by the commerce clause. See, e.g., Exxon Corp. v. Governor of Md., 437 U.S. 117, 127-28 (1978). 
a. Proprietary activity viewed as activity that does not burden interstate commerce

Despite the argument that even proprietary activities can lead to economic Balkanization and therefore should be subject to commerce clause scrutiny, ${ }^{211}$ there are other considerations that may justify use of the governmental-proprietary distinction as a tool of negative commerce clause analysis. When a state prescribes a general rule of private conduct with respect to purchasing, selling, or employment, it affects the market in a way that is often distinguishable in practice if not in principle from the way it affects the market when it acts pursuant to a self-imposed rule of conduct as a purchaser, seller, or employer. In the former case, the state's rule affects every decision to purchase, sell, or hire in the relevant market; in the latter case, it affects only the transactions in which the state itself is involved. The distinction between the state's regulation of the market and its participation in the market on which courts have focused when elaborating on the governmental-proprietary distinction does not, of course, provide a litmus test of the quantitative economic impact of state action on interstate commerce. A massive program of state purchasing to support the price of a locally produced commodity might have a greater impact on interstate commerce than minimum price legislation designed to achieve the same objective. Further, in some markets-for chalk, blackboards, school desks, and the like-the state is the dominant if not the sole actor. ${ }^{212}$ Nevertheless, the distinction between the state's effect on the market through its control of the rules by which market forces operate and its effect on the market through its exercise of its own market power is not irrelevant. Action of the latter sort, it may be suggested, is unlikely under ordinary circumstances to have more than a marginal impact on the natural functioning of the interstate market. ${ }^{213}$ It is this perception that may underlie the tendency to allow a proprietary characterization to render state action invulnerable to commerce clause attack.

Viewed in this light, the governmental-proprietary distinction

211 See Linde, Constitutional Rights in the Public Sector: Justice Douglas on Liberty in the Welfare State, 40 WASH. L. REv. 10, $49-67$ (1965); Note, supra note 209, at 591-95; Comment, supra note 209, at 216-22.

213 See Linde, supra note 211 , at 53-54.

213 This suggestion, however, may not be reasonable. See note 211 supra and accompanying text. 
emerges as a means of identifying state action that does not sufficiently burden interstate commerce so as to imphicate the negative strictures of the commerce clause. It identifies those effects on interstate commerce that courts in the past would have summarily dismissed as "incidental" or "indirect."214 Indeed, even under modern commerce clause analysis, courts must still make the preliminary determination whether state action "affects" or "burdens" interstate commerce so as to warrant an application of the substantive criteria developed under the clause for balancing state and national interests. ${ }^{215}$

If, however, the governmental-proprietary distinction is no more than a convenient device for distinguishing state action which burdens interstate commerce from that which does not, it paints with a brush that does not draw-and, indeed, cannot draw-lines that accurately reflect the commerce clause considerations at issue. Rather than focusing on the precise impact of particular state action in hight of its probable effect on interstate commerce, the distinction focuses on a line between a state's governmental and proprietary activities that may bear no relation to the actual impact of state action on interstate commerce. While the state may ordinarily have only a shight impact on the overall operation of the interstate market when it buys, sells, or hires, this is ultimately an evidentiary question that ought to be addressed as such. No cogent reason, except, perhaps, the desire to limit the expenditure of judicial resources, ${ }^{216}$ exists for not inquiring directly whether particular action substantially affects interstate commerce rather than conducting an inquiry in terms of an artificial distinction designed, at best, to simulate the real one. ${ }^{217}$

b. Proprietary activity viewed as activity in which the state has a business-like interest

Even if the courts ought to abandon the governmental-proprietary distinction in the negative commerce clause context as a

214 See, e.g., Oliver Iron Mining Co. v. Lord, 262 U.S. 172, 179 (1923).

215 See Pike v. Bruce Church, Inc., 397 U.S. 137, 140-42 (1970).

218 Presumably more judicial resources would be expended in the factual inquiry into whether state action burdens interstate commerce than on the determination of whether a state is acting in its governmental or proprietary capacity.

${ }^{217}$ A direct inquiry very similar to this was made in Garden State Dairies, Inc. v. Sills, 46 N.J. 349, 358, 217 A.2d 126, 130 (1966). But see note 202 supra and accompanying text. 
means of identifying state action that has a substantial effect on interstate commerce, it might still be argued that the distinction performs a legitimate function in this context similar to that performed in the area of individual constitutional rights. The state has interests as a purchaser, seller, or employer that are different from and stronger than those it has as a regulator of the general public, and the invocation of the governmental-proprietary distinction may simply be the means by which these interests are taken into account. The difficulties with this attempt to justify the use of the governmental-proprietary distinction do not stem from any theoretical objections to its use in this context. If employed with care, the distinction might well be a suitable vehicle for distinguishing situations in which the government has a strong businesshike interest from those in which it does not. Rather, the problem with such a justification is that it lacks explanatory power in light of the government interests being asserted in situations where the courts have utilized the distinction.

The government no doubt has interests that it shares with private enterprise when it enters the market-purchasing from responsible sellers, selling to creditworthy buyers, hiring trustworthy employees, etc. One might reasonably contend that the commerce clause calculus should account for these interests, perhaps through the use of a properly understood and appropriately limited governmental-proprietary distinction that would allow the government under certain circumstances to prescribe rules for its own market conduct that it could not impose on the market at large. The interests, however, that the government has actually asserted in the commerce clause cases bear no resemblance to these factors. The government, rather, has asserted peculiarly political interests-the desire to provide business, supplies, or employment for its own residents - that do not correspond to interests ordinarily pursued by rational economic actors in the private sector. Whatever role the governmental-proprietary distinction might play in the recognition of the government's legitimate business-like interests, it should not be permitted, under the guise of protecting these interests, to function as a mechanism for according special consideration to the pohtical interests that the government ordinarily pursues. 
c. Proprietary activity viewed as an exercise of state fiscal autonomy in spending its money or otherwise distributing its resources

Use of the distinction might also reflect another consideration bearing on the apphication of the commerce clause to state action: the right of a state to dispose of its resources as it sees flt. If a state is not restrained by the commerce clause from subsidizing instate businesses, ${ }^{218}$ favoring local contractors, ${ }^{219}$ and preferring resident employees, ${ }^{220}$ it may be because courts have determined that it would take more than a "great silence"221 in the Constitution to withdraw from the states the power to distribute their own resources as they deem proper-even when the states exercise the power to serve their own parochial interests at the expense of national economic unity. If this is so, then the governmental-proprietary distinction may be performing a meaningful and analytically defensible function.

To be sure, there is considerable room for controversy over whether the conflict between the purposes of the commerce clause and the power of the states to dispose freely of their own resources ought to be resolved in favor of the latter. The states generally may not violate otherwise applicable constitutional norms merely because they do so through the expenditure of their own funds. ${ }^{222}$ Moreover, it would be difficult to support the position that, regardless of the circumstances, the states are insulated from commerce clause scrutiny whenever they are disposing of their own resources. ${ }^{23}$ Nevertheless, if the cases refusing to subject state

\footnotetext{
218 See Hughes v. Alexandria Scrap Corp., 426 U.S. 794 (1976).

210 See American Yearbook Co. v. Askew, 339 F. Supp. 719 (M.D. Fla.), aff'd mem., 409 U.S. 904 (1972).

220 See Holland v. Bleigh Constr. Co., 61 IIl. 2d 258, 335 N.E.2d 469 (1975).

221 See H.P. Hood \& Sons, Inc. v. Du Mond, 336 U.S. 525, 535 (1949).

${ }^{222}$ See Sugarman v. Dougall, 413 U.S. 634 (1973); Shapiro v. Thompson, 394 U.S. 618 (1969); notes 164-82 supra and accompanying text.
}

${ }^{223}$ See Hellerstein, Hughes v. Oklahoma: The Court, the Commerce Clause, and State Control of Natural Resources, 1979 SuP. CT. REv. 51, 73-84 (1980). The Court has dismissed arguments that the states may discriminate against interstate commerce in their regulation of state highway use because of the states' ownership interests in the roads. See South Carolina State Highway Dep't v. Barnwell Bros., 303 U.S. 177, 187-89 (1938); Buck v. Kuykendall, 267 U.S. 307 (1925). Cf. West v. Kansas Natural Gas Co., 221 U.S. 229, 261-62 (1911) (ownership of state highways rejected as basis for limiting exportation of natural gas from state). Even though the state plainly acts as a regulator in this context, if there were no limits to the theory that the state could favor in-state interests in distributing state-owned resources, one might contend that the state is legitimately providing a state-owned resource (i.e., a higlwway) to in-state interests on a preferential basis. The Court's unwillingness to 
purchasing, selling, and hiring to substantive commerce clause review are to be defended in terms other than the substantiality of the particular action's effect on interstate commerce, the underlying principle may be that the states enjoy considerably more freedom from commerce clause restraints when dealing with their own resources than they do when dealing with the resources of others. ${ }^{224}$ And, what is of primary concern here, the implementation of this principle may be reflected in the courts' application of the governmental-proprietary distinction in this context.

Indeed, recognition of this principle may help explain Hughes $v$. Alexandria Scrap Corp. ${ }^{225}$ - the first Supreme Court decision that squarely confronted these questions ${ }^{228}$-and may illuminate the decision's bearing on the governmental-proprietary distinction. In Hughes the Court upheld a Maryland statute designed to encourage the destruction of abandoned automobiles through payments of cash bounties to scrap processors. The Court found that the statute did not violate the commerce clause, even though the statutory scheme favored in-state interests by imposing more burdensome documentation requirements on out-of-state than on instate processors seeking to qualify for bounties. The Court acknowledged that it faced a "situation ... . without precedent in this Court." sought to "interfer[e] with the natural functioning of the interstate market either through prohibition or through burdensome regula-

countenance state discrimination against instrumentalities of interstate commerce regardless of any asserted ownership interest by the states in their highways not only undermines this theory but further suggests that the Court might well find limits to the states' fiscal autonomy under the commerce clause's negative imphications even when the state is not acting in a regulatory capacity.

224 See Hellerstein, supra note 223, at 73-84.

225426 U.S. 794 (1976).

236 See also Reeves, Inc. v. Stake, 100 S. Ct. 2271 (1980), discussed in the postscript of notes 252-63 infra and accompanying text. The Court has affirmed summarily a decision of a federal district court that rehed on the governmental-proprietary distinction in sustaining an in-state purchasing preference over commerce clause objections. See American Yearbook Co. v. Askew, 409 U.S. 904, aff'g mem. 339 F. Supp. 719 (M.D. Fla. 1972). Some early decisions may also be construed as permitting the states to dispose of their own resources free from commerce clause scrutiny, see, e.g., Field v. Barber Asphalt Paving Co., 194 U.S. 618, 622-23 (1904) (commerce clause no bar to local government contract requiring the purchase of out-of-state materials), but they were decided on the now discredited ground that the act only "indirectly" rather than "directly" affected interstate commerce.

227426 U.S. at 807. 
tion"228 from the case before it in which the state had "entered into the market itself" 228 "as a purchaser, in effect, of a potential article of interstate commerce."230 The Court concluded that "[n]othing in the purposes animating the Commerce Clause prohibits a State ... from participating in the market and exercising the right to favor its own citizens over others."231

Hughes has been read ${ }^{232}$ and criticized ${ }^{233}$ as embracing a governmental-proprietary distinction as a means of delineating the scope of the negative implications of the commerce clause. The criticism, however, is based on a limited view of the distinction's role in this context. If the distinction serves only to identify state action having a substantial effect on interstate commerce, it is, as suggested above, ${ }^{234}$ a poor and unnecessary substitute for an inquiry into the practical impact that particular state action actually has on interstate commerce. The Court, however, in explicitly rejecting the "premise ... that every action by a State that has the effect of reducing in some manner the flow of goods in interstate commerce is potentially an impermissible burden," ${ }^{235}$ plainly did not rely on a governmental-proprietary distinction as a proxy for the substantiality of the state action's impact on interstate commerce. Whatever impact the action might have had, it was not "the kind of action with which the Commerce Clause is concerned."2s8

Nor can it plausibly be argued that the Court illicitly used the governmental-proprietary distinction to distinguish between the state's political and business-like interests in order to limit the implied restraints of the commerce clause on state action. The court below refused to characterize the state's activities as "proprietary" because "the State has not chosen to contract in a business context

228 Id. at 806.

220 Id.

2so Id. at 808.

ssi Id. at 810 (footnotes omitted).

${ }^{232}$ See, e.g., Note, Constitutional Law-Commerce Clause-State Purchasing Activity Excluded from Commerce Clause Review - Hughes v. Alexandria Scrap Corp., 18 B.C. INDus. \& Com. L. Rev. 893, 910-12 (1977) [hereinafter cited as State Purchasing Activity]; Note, Proprietary Powers: A New Policy Tool for the States?, 31 U. Miam L. REv. 729, 73234 (1977) [hereinafter cited as Proprietary Powers].

2ss See, e.g., State Purchasing Activity, supra note 232, at 921-23; Proprietary Powers, supra note 232 , at 734-35.

2si See notes 211-17 supra and accompanying text.

238426 U.S. at 805.

2ss $I d$. 
with scrap processors and to specify conditions with respect to the latters' [sic] performance of such contracts," suing "traditional governmental"2s8 goals. The Supreme Court's opinion is fully consistent with that judgment. The Court recognized that the state entered the market to protect the state's environment, ${ }^{239}$ a typically governmental pursuit.

Hughes may also be read, however, as embracing a governmental-proprietary distinction that reflects the state's interest in its fiscal autonomy. ${ }^{240}$ At several points in its opinion, the Court adverts to the fact that "the payment of state funds," largesse,"242 or "money from the State," were at issue and indicates that this fact in itself may bear on the scope of the negative implications of the commerce clause. ${ }^{244}$ If the commerce clause does not confine the states' power to spend their money as they see fit, the reason may be that fundamental considerations relating to the essential role of the states in the federal system are deemed to require state autonomy in this area; and this may be so even though the exercise of the power to further parochial economic interests offends important values underlying the commerce clause. Insofar as the governmental-proprietary distinction serves as a mechanism for accommodating these competing interests, it may permit the courts to resolve a hard problem without articulating the difficulties and exposing some of the sensitive nerves of our constitutional scheme. If the distinction serves even this limited purpose, courts may less easily dispense with it than if it serves as no more tban a proxy for a factual determination that can best be made by examinuig the facts themselves. Courts may not be willing to discard a distinction that allows them to reach results that they feel are correct but that nevertheless offend values to which

\footnotetext{
237 Alexandria Scrap Corp. v. Hughes, 391 F. Supp. 46, 55 (D. Md. 1975), rev'd, 426 U.S. 794 (1976).

2ss Id.

239426 U.S. at 809.

210 This argument may derive imphicit support from the fact that Hughes was decided on the same day as National League of Cities v. Usery, 426 U.S. 833 (1976), discussed at notes 67-75 supra and accompanying text. See also Reeves, Inc. v. Stake, 100 S. Ct. 2271 (1980), discussed at notes 252-63 infra and accompanying text.

24426 U.S. at 809.

$212 I d$.

243 Id. at 810 .

24 Id. at $809-10$.
} 
they are committed. If the cases in this area ultimately reflect the judgment that the states' interest in distributing their own resources as they see fit overrides the nation's interest in unfettered commerce among the states, then the governmental-proprietary distinction may be performing a constructive function in commerce clause analysis.

A further question is whether a better method exists for achieving the accommodation between state fiscal autonomy and the purposes of the commerce clause than using a governmental-proprietary distinction. The answer depends on one's view of the nature of the appropriate accommodation. If one views the process of accommodation as no different in substance from the accommodation of other interests under the commerce clause, there is no cogent reason for not candidly balancing the interests-the importance of the state's interest in its fiscal autonomy and the extent to which the national economy is Balkanized-and making an informed judgment under the facts of the case. If, however, one has concluded as a matter of principle that the state's interest in spending its money as it sees fit will always prevail over the values protected by the commerce clause-a conclusion that is consistent with, though not compelled by, language in Hughes-then reliance on the governmental-proprietary distinction as a decisional mechanism may produce satisfactory results, even if it obscures the underlying rationale for them.

Two final points are worthy of attention in connection with the governmental-proprietary distinction in negative commerce clause analysis. First, an instructive contrast can be drawn between the constitutional rights cases and those presenting negative commerce clause problems. In the former, the government's position as a proprietor can supply a strong quasi-business interest that may, but does not necessarily, diminish the constitutional protection afforded the individual who contracts with the government. In the latter, the government acting as a proprietor remains free of commerce clause restraints. One question that arises is why, if state autonomy is sufficient to bar any commerce clause restraints, should it not similarly bar assertions of constitutional rights. The answer is that while the state's business interests can be considered in determining the scope of constitutional rights, the state's autonomy is subordinate to those rights. Otherwise those rights would have no value beyond what the state chose to give them. In 
contrast, the negative implications of the commerce clause arise not out of rights held by individuals against the state but rather out of the national interest in unfettered interstate commerce. Recognizing that state autonomy requires that some state proprietary activities not be subject to the negative restraints of the commerce clause does not threaten the individual's rights against the state. $^{245}$

Second, in the commerce clause context, the state retains its autonomy where it acts as a proprietor. In the eleventh amendment context, the state's autonomy is protected when it acts in a governmental capacity. The apparent inconsistency between these two doctrines vanishes upon closer examination. The governmentalproprietary distinction drawn in the negative commerce clause cases shares nothing except a common name with the distinction employed in the eleventh amendment context. The autonomy the former defends is the state's ability to use its resources as it wishes, while in eleventh amendment law the distinction protects states against the power of federal courts to render damage remedies against them. What we have is not necessarily a capricious use of the empty term "governmental-proprietary distinction," but two different kinds of state autonomy, protected and limited by two different distinctions among government activities.

\section{The Governmental-Proprietary Distinction: An Evaluation}

Having described the constitutional contexts where courts have invoked the governmental-proprietary distinction, we may briefly state our central conclusions regarding the nature of the distinc-

\footnotetext{
${ }^{215}$ Even in those rare instances in which the Court has held the commerce clause to be the source of what are usually considered rights held by individuals against the state (e.g., the right to travel), the Court generally has couched its commerce clause analysis in terms of whether the national interest in unfettered commerce outweighs the state's interest in pursuing legitimate local policies, not in terms of whether the state had unconstitutionally limited an individual's right. See Edwards v. California, 314 U.S. 160 (1941). Moreover, the broad power of Congress to consent to state laws that would violate the negative implications of the commerce clause in the absence of such consent, see Prudential Ins. Co. v. Benjamin, 328 U.S. 408, 434-36 (1946); Southern Pac. Co. v. Arizona, 325 U.S. 761, 769 (1945); In re Rahrer, 140 U.S. 545 (1891), indicates that the national interest in unfettered commerce, not an individual's right to engage in interstate commerce, is the ultimate source of negative commerce clause doctrine. See also Choper, The Scope of National Power Vis$a$-Vis the States: The Dispensability of Judicial Review, 86 YaLE L.J. 1552, 1554-57 (1977).
} 
tion and its proper place in constitutional analysis. First, the governmental-proprietary distinction lacks fixed content. Its content in a given area depends on the purposes for which it is used, and these purposes differ from one area to another. Thus, governmental activities that are proprietary in negative commerce clause analysis or in dehneating the constitutional rights of individuals may be governmental in eleventh amendment law. The terms "governmental" and "proprietary" are best viewed as labels expressing the conclusion that particular government activity should be accorded a particular legal status and not as standards to be used in reaching such a conclusion.

Second, because the content of the governmental-proprietary distinction depends on the purposes for which it is drawn, the distinction is not indispensable. Courts could pursue each of the purposes it serves by focusing directly on the underlying values themselves - the recognition of state autonomy in connection with the disposition of the state's own resources, the accommodation of state independence from federal judicial power with the individual's interest in a federal forum to assert rights against the state, or the state's business-like interest in freedom from strict constitutional restrictions when it deals with its employees. As the Court itself ultimately recognized, for example, the immunity of the states from federal taxation could be delineated by inquiring directly into the extent of the interference with the state's ability to function in the federal system and the impact on federal revenues without reference to wliether the activity taxed was governmental or proprietary.

Third, although the governmental-proprietary distinction itself is dispensable, the accommodating function it performs is not. Even if courts abandoned the governmental-proprietary distinction, it would still be necessary to reach accommodations among the conflicting interests that are reconciled under its rubric: the conflict between federal taximg and regnlatory power and the ability of the states to function as independent entities in the federal system; the conflict between the state's interest in immunity from private lawsuit in federal court and an individual's interest in the availability of a forum for the redress of wrongs; the conflict between the state's interest as an employer, a lender, or a landlord and the individual's interest in placing limits on the state's authority over him; and the conflict between the state's interest in dis- 
posing freely of its own resources and the nation's interest in unfettered interstate commerce.

Fourth, the governmental-proprietary distinction is a source of considerable confusion. Because of the natural tendency to assume that the same words have the same meaning in different contexts, the distinction has been employed in ways that do not reflect the different significance it ought to be given in different contexts. As a result, its content in any particular context becomes confused and distorted.

In view of the dispensability of the governmental-proprietary distinction and the confusion it generates, the question arises whether it should be discarded altogether as a tool of constitutional analysis. The answer may lie in whether its value in serving a variety of goals is worth the confusion. The distinction, in the end, is properly viewed as a means for expressing the relationship between a set of facts and a legal conclusion that can be drawn from those facts, but one which possesses no independent meaning of its own. In this it is like otlier terms in the law sucll as "riglit," "duty," and "ownerslip" that do not stand for anything but a distinct function: connecting sets of facts to legal consequences. ${ }^{248}$

Words such as these serve useful purposes in the law. They enable us to express in a single word or phrase the connection between a set of factual conditions and a set of legal consequences. To be sure, one could get along witlout them. One could, for example, express the legal rules concerning ownership by directly specifying the individual factual conditions that give rise to individual legal consequences: if $A$ has purcliased a peppercorn, he may recover its possession from others; if $A$ lias inherited a peppercorn, he may recover damages for its willful destruction; etc. ${ }^{247}$ By the same token, one could express the legal rules relating to the governmental-proprietary distinction by directly specifying the individual factual conditions that give rise to individual legal consequences: if a state restricts the private purchase of widgets to instate sources, its action will be subject to commerce clause scrutiny; if the state restricts its own purchase of widgets to in-state sources, its action will not be subject to commerce clause scrutiny;

246 See Hart, Definition and Theory in Jurisprudence, 70 LAw. Q. REv. 37 (1954); Ross, $T \hat{u}-T \hat{u}, 70$ Harv. L. REv. 812 (1957). The ensuing discussion draws heavily on these articles.

${ }^{247}$ See Ross, supra note 246, at 823. 
etc. It is apparent, however, that if one were compelled always to deal at this level of specificity, the analysis of legal problems would at times become extremely cumbersome. It is often convenient to have a way of talking about the relationship between facts and consequences that terms like "ownership" and the "governmentalproprietary distinction" signify. Indeed, it has been suggested that it is the task of legal thinking to reduce the relationship between factual conditions and legal consequences to systematic order by means of presenting them plainly and conveniently, and that the use of terms like these is one such means. ${ }^{248}$

There is, however, a danger in employing such terms, as the substantive discussion in this article has suggested. The danger is that these terms, whose function is to relate facts to consequences and which have no fixed meaning independent of their function, will nevertheless be assumed to have such a meaning. Thus, one may attempt to define "ownership" in terms of legal facts that are deemed to give rise to it (purchase, inheritance, etc.) or legal consequences that are deemed to follow from its existence (repossession, recovery of damages, etc.) or both. Such attempts, however, are doomed to fail because, rather than meaning anything, "ownership" merely stana's for something, namely the relationship between the fact and the consequence. ${ }^{249}$ Similarly, any attempt to give fixed content to the words "governmental" or "proprietary" in terms of the facts that are central to their definition (e.g., a state's operation of a commercial enterprise) or in terms of legal consequences that follow from such a characterization (e.g., a state's vulnerability to suit in federal court) will be fruitless. Again, the terms do not "mean" anything beyond what they stand for-for example, the relationship between the fact of a state's running a railroad and the consequence of its amenability to suit in federal court.

This futile search for substantive content in terms that are in essence no more than connecting links between conditioning facts and legal consequences cannot be dismissed as a harmless waste of time because it obscures the analysis of legal issues in which the terms are employed. If one beheves that the "essence" of "ownership" is the power to dispose of something as one wishes, one will

${ }^{248}$ See id. at 819.

249 See Hart, supra note 246, at 45-53; Ross, supra note 246, at 822-23. 
become confused in dealing with many uses of the term "ownership" where this turns out not to be the case. ${ }^{250}$ Likewise, if one beheves that the "essence" of the term "governmental" embraces a state's regulation of the wages, hours, and conditions of public employment, one will become confused in dealing with the term "governmental" in contexts where this turns out not to be the case.

Ultimately, the value of terms like "ownership" and "the governmental-proprietary distinction" depends on whether their benefits are wortl their costs. If the tendency to attribute fixed meaning to terms that liave none and the consequent confusion in analyzing legal problems impose more costs on the legal system than the benefits of being able to talk systematically about a set of factual conditions and legal consequences, then such terms should be abandoned. Of course, eacli such term must be evaluated on its own merits. From a practical standpoint, it makes little sense to talk about discarding the term "ownership." The term is too firmly embedded in our legal system to be extracted from it without generating unacceptable costs. The governmental-proprietary distinction, however, despite its longevity, does not play such a pervasive role, and, if the case against it were strong enough, a persuasive argument could be made for abandoning it altogether.

Whether the benefits of tlie governmental-proprietary distinction are worth its costs is a matter of judgment, and the authors have reached no firm conclusions on this score. It may be suggested, however, that we are hkely to be living with the distinction for the foreseeable future, and tliat we should at least recognize it for what it is. ${ }^{251}$

\section{POSTSCRIPT}

While this article was in galleys, the Supreme Court lianded down its decision in Reeves, Inc. $v$. Stake, ${ }^{252}$ to which we have alluded above. ${ }^{253}$ The issue in Reeves was whether the commerce

\footnotetext{
${ }^{280}$ See, e.g., Trelease, Government Ownership and Trusteeship of Water, 45 CaLIF. L. Rev. 638 (1957).

2s1 Professor Hart demonstrates that "legal words like 'right,' 'duty,' 'State,' or 'corporation" " cannot be defined if by definition we mean "provision of a synonym which will not equally puzzle us." Hart, supra note 246 , at $46-47$. Such words can, however, be elucidated by describing the conditions under which they should be used. See id. at 47-49.

282100 S. Ct. 2271 (1980).

${ }^{235}$ See notes 194, 226, and 240 supra.
} 
clause forbade South Dakota, which owned and operated a cement plant, from refusing to sell cement to out-of-state customers in accordance with its policy of supplying all South Dakota customers first. The Court, relying heavily on its opinion in Hughes v. Alexandria Scrap Corp. ${ }^{254}$ held that South Dakota's action did not violate the commerce clause: "The basic distinction drawn in Alexandria Scrap between States as market participants and States as market regulators makes good sense and sound law." ${ }^{255}$ Characterizing the state activity at issue as "proprietary,"256 the Court declared that "when acting as proprietors, States should ... share existing freedoms [enjoyed by private market participants] from federal constraints, including the inherent limits of the Commerce Clause." "25z At the same time, the Court found support for its holding in "considerations of state sovereignty":258

Considerations of sovereignty independently dictate that marketplace actions involving "integral operations in areas of traditional governmental functions" . . . may not be subject even to congressional regulation pursuant to the commerce power. National League of Cities $v$. Usery . . . I It follows easily that the intrinsic limits of the Commerce Clause do not prohibit state marketplace conduct that falls within this sphere. Even where "integral operations" are not implicated, States may fairly claim some measure of a sovereign interest in retaining freedom to decide how, with whom, and for whose benefit to deal. ${ }^{259}$

The Court's opinion in Reeves reinforces our earher discussion of the role of the governmental-proprietary distinction in negative commerce clause analysis. First, Reeves explicitly approves the virtually unbroken line of cases holding that a state's action in its proprietary capacity gives rise to no commerce clause objection. ${ }^{280}$ Second, Reeves reiterates the argument traditionally advanced for immunizing the state as a proprietor from commerce clause scrutiny, namely, that when a state acts as a private business it should

284 426 U.S. 794 (1976). For a discussion of Hughes, see text accompanying notes 225-44 supra.

2ss 100 S. Ct. at 2277.

2 se See id. at 2278-79.

257 Id. at 2279.

$2 \$ 8$ Id. at $2277-78$.

258 Id. at 2278 n.10.

${ }^{280}$ Id. at 2277 \& n.9. See notes 191-204 supra and accompanying text. 
be treated as a private business for commerce clause purposes. ${ }^{261}$ Finally, by recognizing "considerations of state sovereignty" ${ }^{262}$ in arriving at its conclusion, Reeves provides a substantive rationale for use of the governmental-proprietary distinction that may give it viability in this context. ${ }^{268}$

261 $100 \mathrm{~S}$. Ct. at 2278-79. See note 196 supra and accompanying text.

${ }_{262} 100 \mathrm{~S}$. Ct. at 2277-78.

263 See notes 218-44 supra and accompanying text. 
Copyright 1980 Virginia Law Review, used by permission 